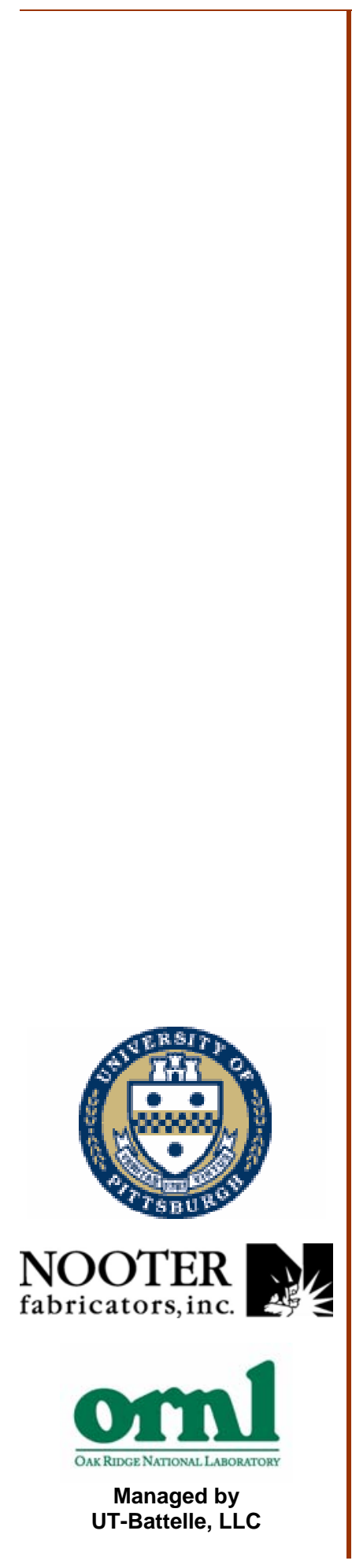

Final Technical Report

Fracture Toughness and Strength in a New Class of Bainitic Chromium-Tungsten Steels

June 2006

Principal Investigators:

Dr. Scott X. Mao

University of Pittsburgh

Dr. Vinod K. Sikka

Oak Ridge National Laboratory 


\section{DOCUMENT AVAILABILITY}

Reports produced after January 1, 1996, are generally available free via the U.S. Department of Energy (DOE) Information Bridge.

Web site http://www.osti.gov/bridge

Reports produced before January 1, 1996, may be purchased by members of the public from the following source.

National Technical Information Service

5285 Port Royal Road

Springfield, VA 22161

Telephone 703-605-6000 (1-800-553-6847)

TDD 703-487-4639

Fax 703-605-6900

E-mail info@ntis.fedworld.gov

Web site http://www.ntis.gov/support/ordernowabout.htm

Reports are available to DOE employees, DOE contractors, Energy Technology Data Exchange (ETDE) representatives, and International Nuclear Information System (INIS) representatives from the following source.

Office of Scientific and Technical Information

P.O. Box 62

Oak Ridge, TN 37831

Telephone 865-576-8401

Fax 865-576-5728

E-mail reports@osti.gov

Web site http://www.osti.gov/contact.html 


\section{FINAL PROJECT REPORT}

Project Title:

Award Number:

Project Period:

PI(s):

Additional Researchers:

Recipient Organization:

National Laboratory:
Fracture Toughness and Strength in a New Class of Bainitic Chromium-Tungsten Steels

DE-FC07-01ID14253

October 2001-September 2005

Dr. Scott X. Mao

(412) 624-9602

smao@engrng.pitt.edu

Dr. Vinod K. Sikka

(865) 574-5112

sikkavk@ornl.gov

Dr. Chen Zheng

(519) 888-4567

z3cheng@mecheng1.uwaterloo.ca

University of Pittsburgh

Department of Mechanical Engineering

3700 O'Hara St.

Pittsburgh, PA 15261

Oak Ridge National Laboratory

One Bethel Valley Road

P.O. Box 2008

Oak Ridge, TN 37831

Nooter Fabrication Services, Inc. 



\title{
Fracture Toughness and Strength in a New Class of Bainitic Chromium-Tungsten Steels
}

\author{
Dr. Scott X. Mao \\ University of Pittsburgh \\ Dr. Vinod K. Sikka \\ Oak Ridge National Laboratory
}

June 2006

Prepared by

OAK RIDGE NATIONAL LABORATORY

P.O. Box 2008

Oak Ridge, Tennessee 37831-6283

managed by

UT-Battelle, LLC

for the

U.S. DEPARTMENT OF ENERGY

under contract DE-AC05-00OR22725 


\section{Acknowledgments and Disclaimer}

\section{Acknowledgments}

This report is based upon work supported by the U.S. Department of Energy, Energy Efficiency and Renewable Energy, Industrial Technologies Program, Industrial Materials for the Future, under Award No. DE-FC07-01ID14253.

The research at Oak Ridge National Laboratory was sponsored by the U.S. Department of Energy, Office of Energy Efficiency and Renewable Energy, Industrial Technologies Program, under contract DE-AC05-00OR22725 with UT-Battelle, LLC. The authors wish to thank Dr. Peter Angelini for program direction and reviewing the document, Millie Atchley for document preparation, and Carolyn Moser for technical editing.

\section{Disclaimer}

This report was prepared as an account of work sponsored by an agency of the United States Government. Neither the United States Government nor any agency thereof, nor any of their employees, makes any warranty, express or implied, or assumes any legal liability or responsibility for the accuracy, completeness, or usefulness of any information, apparatus, product, or process disclosed, or represents that its use would not infringe privately owned rights. Reference herein to any specific commercial product, process, or service by trade name, trademark, manufacturer, or otherwise, does not necessarily constitute or imply its endorsement, recommendation, or favoring by the United States Government or any agency thereof. The views and opinions of authors expressed herein do not necessarily state or reflect those of the United States Government or any agency thereof. 


\section{Contents}

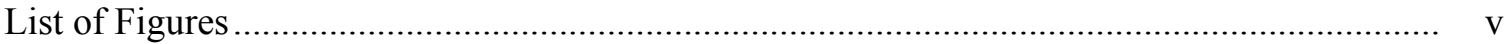

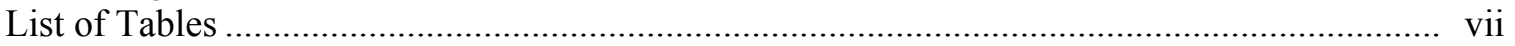

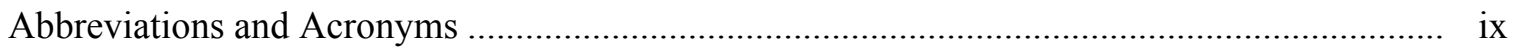

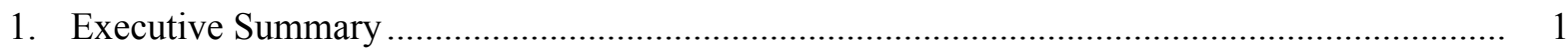

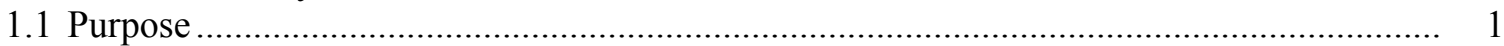

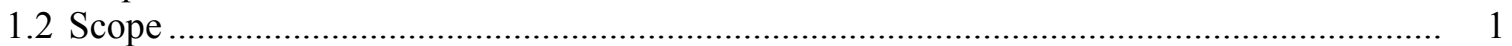

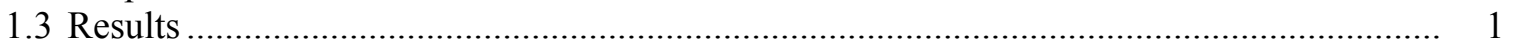

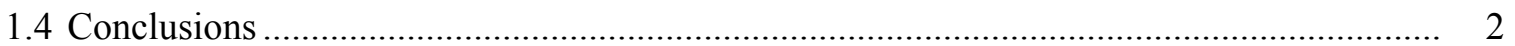

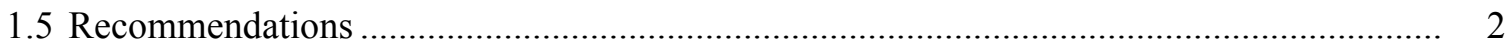

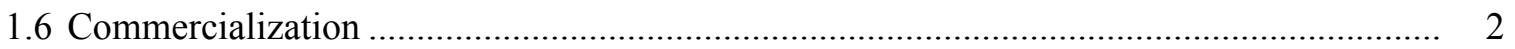



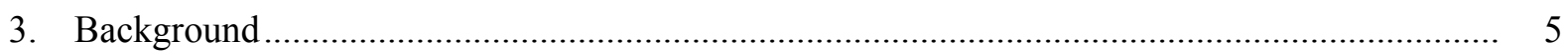

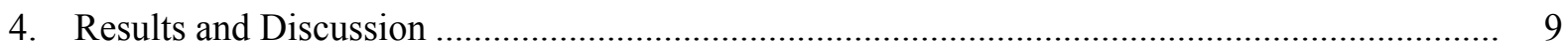

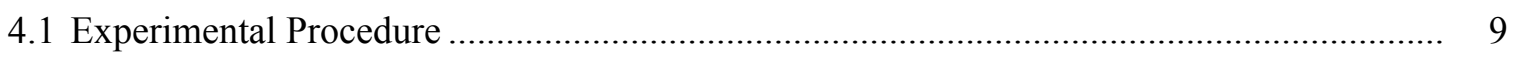

4.2 Optical and TEM Analysis on Microstructure ….............................................................. 9

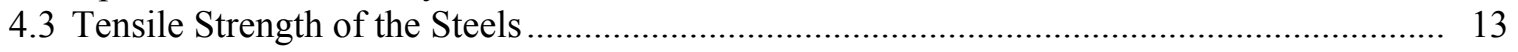

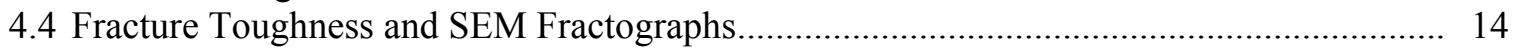

4.5 Effect of PWHT on Fracture Toughness and Strength Distribution of Welding Joints ........ 17

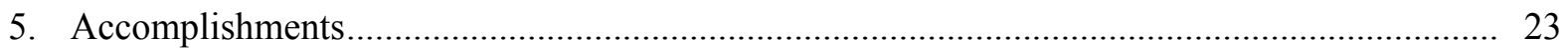

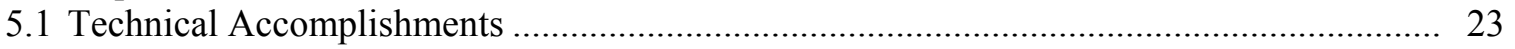

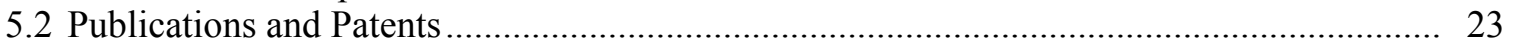



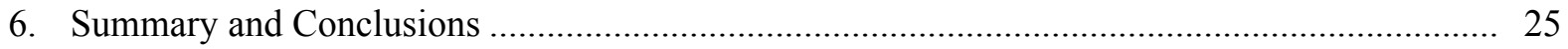



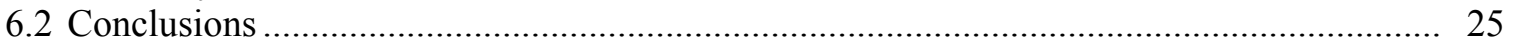

6.3 Commercialization Aspects: Plans, Status, Barriers ...................................................... 26

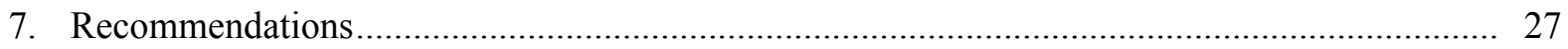

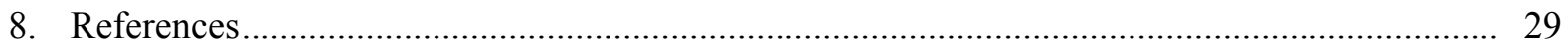





\section{List of Figures}

2.1 Organizational plan for project coordination and management........................................ 3

3.1 Microstructures of (a) normalized and (b) normalized-and-tempered 3Cr-3WV steels.......... 7

4.1 Microstructure of (a) normalized and (b) normalized and tempered 3Cr-3WVTa steels......... 10

4.2 Transmission electron photomicrographs of the bainite microstructure of 3Cr-3WV steel: (a) normalized and (b) normalized and tempered. ................................... 10

4.3 Transmission electron photomicrographs of the bainite microstructure of 3Cr-3WVTa steel: (a) normalized; (b) normalized and tempered.................................... 11

4.4 Transmission electron microscopy micrographs of extraction replicas of (a) normalized 3Cr-3WV steel and (b) normalized and tempered 3Cr-3WV steel.....

4.5 Transmission electron microscopy micrographs of extraction replicas of $3 \mathrm{Cr}-3 \mathrm{WVT}$ a steel.

4.6 Energy dispersive X-ray spectrum and microbeam diffraction pattern of particles shown in Fig 4.5

4.7 Transmission electron microscopy dark-field image of extraction replica showing fine carbides formed in normalized and tempered 3Cr-3WVTa steel

4.8 Scanning electron microscopy fractographs of (a) normalized 3Cr-3WV steel and (b) normalized 3Cr-3WVTa steel.

4.9 Scanning electron microscopy fractographs of normalized and tempered steels

4.10 Schematic of difference in ductile-brittle transition temperature (DBTT) between $3 \mathrm{Cr}-3 \mathrm{WV}$ and $3 \mathrm{Cr}-3 \mathrm{WVTa}$ steels.

4.11 Typical microstructure of base metal, showing acicular bainite without polygonal ferrite.

4.12 Macrosection of welded joint showing base metal, heat-affected zone (HAZ), and the weld metal.

4.13 Metallograph of weld joint showing base metal, heat-affected zone, and weld metal.

4.14 Microstructure of grain-coarsened heat-affected zone.

4.15 Microstructures of weld metals

4.16 Microhardness measurement results across the weld in the as-welded condition.

4.17 Schematic showing the positions of heat-affected-zone and base-metal compact tension samples taken from the welded joint.

4.18 Comparison of fracture toughness between of heat-affected zone and base metal

4.19 Scanning electron microscopy fractographs of HAZ specimens

4.20 Scanning electron microscopy fractographs of HAZ specimen with and without PWHT 



\section{List of Tables}

4.1 Chemical composition of 3Cr3WV and 3Cr3WVTa steels ............................................. 9

4.2 Typical microstructural parameters of the 3Cr-3WV and 3Cr-3WVTa steel ....................... 13

4.3 Strength and fracture toughness of the 3Cr3WV and 3Cr3WVTa steels ............................. 14

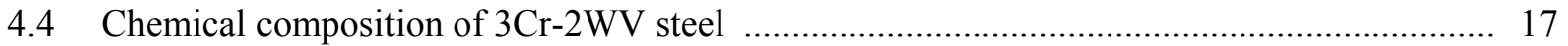

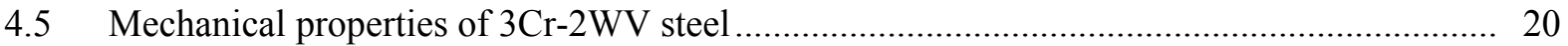





\section{Abbreviations and Acronyms}

$\begin{array}{ll}\text { CT } & \text { compact tension } \\ \text { DBTT } & \text { ductile-brittle transition temperature } \\ \text { DOE } & \text { U.S. Department of Energy } \\ \text { EDX } & \text { electron diffraction X ray } \\ \text { GTA } & \text { gas tungsten arc } \\ \text { HAZ } & \text { heat-affected zone } \\ K_{I C} & \text { fracture toughness } \\ \text { M-A } & \text { martensite-austenite } \\ \text { N } & \text { normalized } \\ \text { NT } & \text { normalized and tempered } \\ \text { OM } & \text { optical microscopy } \\ \text { ORNL } & \text { Oak Ridge National Laboratory } \\ \text { PWHT } & \text { postweld heat treatment } \\ \text { SA } & \text { submerged arc } \\ \text { SEM } & \text { scanning electron microscopy } \\ \text { TEM } & \text { transmission electron microscopy } \\ \text { USE } & \text { upper shelf energy }\end{array}$





\section{Executive Summary}

\subsection{Purpose}

This project dealt with developing an understanding of the toughening and strengthening mechanism for a new class of Fe-3Cr-W(V) steels developed at Oak Ridge National Laboratory (ORNL) in collaboration with Nooter Corporation and other industrial partners. The new steel had $50 \%$ higher tensile strength up to $650^{\circ} \mathrm{C}$ than currently used steels and the potential for not requiring any postweld heat treatment (PWHT) and for reducing equipment weight by $25 \%$. This project was closely related to the Nooter project described in the report Development of a New Class of Fe-3Cr-W(V) Ferritic Steels for Industrial Process Applications (ORNL/TM-2005/82). The project was carried out jointly by the University of Pittsburgh and ORNL. The University of Pittsburgh carried out fracture toughness measurements and microstructural analysis on base metal and welded plates prepared at ORNL.

\subsection{Scope}

The project focused on three areas. The first dealt with detailed microstructural analysis of base compositions of $3 \mathrm{Cr}-3 \mathrm{WV}$ and $3 \mathrm{Cr}-3 \mathrm{WV}(\mathrm{Ta})$ in both normalized $(\mathrm{N})$ and normalized and tempered (NT) conditions. The second aspect of the project dealt with determining tensile properties and fracture toughness values of $\mathrm{K}_{\mathrm{IC}}$ at room temperature for both $3 \mathrm{Cr}-3 \mathrm{Wv}$ and $3 \mathrm{Cr}-3 \mathrm{WV}(\mathrm{Ta})$ compositions. The third focus of the project was to measure the fracture toughness values of the base metal and the heat-affected zone (HAZ) of a plate of Fe-3Cr-W(Mo)V steel plate welded by the gas tungsten arc (GTA) process. The HAZ toughness was measured in both the as-welded and the PWHT condition.

\subsection{Results}

Both 3Cr-3WV and 3Cr-3WV(Ta) alloys showed the presence of an acicular bainitic structure. The tantalum addition of $0.1 \mathrm{wt} \%$ decreased the prior austenite grain size of $3 \mathrm{Cr}-3 \mathrm{WV}$ steel by nearly a factor of 2 . However, the bainite packet size was only slightly affected by the addition of tantalum. The tantalum-containing steel showed the presence of $\mathrm{TaC}$ in the $\mathrm{N}$ condition. No precipitates were observed in $3 \mathrm{Cr}-3 \mathrm{WV}$ steel in the $\mathrm{N}$ condition. A tempering treatment of $700^{\circ} \mathrm{C}$ resulted in carbide precipitation at the grain boundaries and in the matrix of the $3 \mathrm{Cr}-3 \mathrm{WV}$ steel. For $3 \mathrm{Cr}-3 \mathrm{WV}(\mathrm{Ta})$, the tempering treatment further precipitated $\mathrm{TaC}$ at the grain boundaries and in the matrix. The carbide particle size at the grain boundaries and in the matrix was finer $(\sim 1 / 2-1 / 3)$ for $3 \mathrm{Cr}-3 \mathrm{WV}(\mathrm{Ta})$ steel than for $3 \mathrm{Cr}-3 \mathrm{WV}$.

The $\mathrm{K}_{\mathrm{IC}}$ fracture toughness values for both $3 \mathrm{Cr}-3 \mathrm{WV}$ and $3 \mathrm{Cr}-3 \mathrm{WV}(\mathrm{Ta})$ were very similar in both the $\mathrm{N}$ and the NT conditions. After tempering, the $\mathrm{K}_{\mathrm{IC}}$ values of both steels improved by $\sim 10 \%$.

The GTA weld in the steel composition of $3 \mathrm{Cr}-\mathrm{W}(\mathrm{Mo}) \mathrm{V}$ developed for commercial applications was tested for its $\mathrm{K}_{\mathrm{IC}}$ values in the base metal and HAZ. The $\mathrm{K}_{\mathrm{IC}}$ values in HAZ were also determined after PWHT. Data showed that the $\mathrm{K}_{\mathrm{IC}}$ values of HAZ in the as-welded and PWHT conditions were similar to the values for the base metal. These observations suggest that the GTA welds can be used in the as-welded conditions. 


\subsection{Conclusions}

Three major conclusions can be drawn from this project:

1. The $0.1 \mathrm{wt} \%$ tantalum addition to $3 \mathrm{Cr}-3 \mathrm{WV}$ steel is very effective in refining the prior austenite grain size and produces finer carbides at grain boundaries and in the matrix than in $3 \mathrm{Cr}-3 \mathrm{WV}$.

2. The $K_{I C}$ fracture toughness values of $3 \mathrm{Cr}-3 \mathrm{WV}$ and $3 \mathrm{Cr}-3 \mathrm{WV}(\mathrm{Ta})$ are similar under both $\mathrm{N}$ and NT conditions. This implies that the $3 \mathrm{Cr}-3 \mathrm{WV}$ or $3 \mathrm{Cr}-3 \mathrm{WV}(\mathrm{Ta})$ steels can be used in either the $\mathrm{N}$ or the NT condition.

3. The $K_{I C}$ fracture toughness of HAZ in GTA is the same as for the base metal in both as-welded and PWHT conditions. This implies that the GTA welds can be used without the need for PWHT.

\subsection{Recommendations}

The fracture toughness $\mathrm{K}_{\mathrm{IC}}$ measurements should be determined for the base metal, HAZ, and weld metal for submerged arc (SA) welded plates from the final steel compositions consisting of $3 \mathrm{Cr}-$ $2 \mathrm{~W}(\mathrm{Mo}) \mathrm{V}$. This is needed because SA will be the most commonly used process in the production of chemical reactors from these steels.

\subsection{Commercialization}

The $\mathrm{K}_{\mathrm{IC}}$ measurements from this project will help in the early approval of ASME code for the final $3 \mathrm{Cr}-2 \mathrm{~W}(\mathrm{Mo}) \mathrm{V}$ steel composition. An earlier ASME code approval will speed up the commercial applications of the final steel composition known as Grade 315, which was developed in a related industry-led project. 


\section{Introduction}

The performance of the materials used in the construction of equipment for many industrial processes, including chemical process equipment, is related to their strength and fracture toughness. Among the many such industrial materials, $\mathrm{Fe}-2.25 \mathrm{Cr}$-Mo steel is used extensively for hydrocrackers, hydrotreaters, and industrial heat recovery systems. Some of the chemical process equipment fabricated from $\mathrm{Fe}-2.25 \mathrm{Cr}-1 \mathrm{Mo}$ can be as large as 100 to 300 tons. The manufacture of this equipment requires postweld heat treatment (PWHT) that can be carried out in the shop environment. However, the requirements of PWHT limit the possibility of making changes to the unit in the field. The need to reduce the size of the PWHT equipment - and the possibility of making equipment changes in the field, without requiring PWHT-led to the development of a new class of ferritic steels. These steels are based on Fe-3Cr-3WV, Fe-3Cr-3WV(Ta), and Fe-3Cr-2W(Mo)V compositions and were targeted to (1) produce up to $50 \%$ higher tensile strength than that of currently used steels in this class, (2) provide the potential for eliminating PWHT for certain types of welding processes, and (3) reduce equipment weight by $25 \%$. New steel compositions meeting these requirements were developed at Oak Ridge National Laboratory (ORNL) in collaboration with Nooter Corporation and other industrial partners, as reported in Development of a New Class of Fe-3Cr-W(V) Ferritic Steels for Industrial Process Applications (ORNL/TM-2005/82).

The current project dealt with detailed microstructural characterization of this new class of steels and measuring $\mathrm{K}_{\mathrm{IC}}$ fracture toughness properties of the base metal and heat-affected zone (HAZ) of the weld prepared by the gas tungsten arc (GTA) process. The project was carried out jointly by the University of Pittsburgh and ORNL. The University of Pittsburgh carried out fracture toughness measurements and microstructural analysis on base metal and welded plates prepared at ORNL. The functional organization for the project is shown in Fig. 2.1.



Fig. 2.1. Organizational plan for project coordination and management. 



\section{Background}

An exhaustive literature exists on the microstructure and properties of $\mathrm{Fe}-2.25 \mathrm{Cr}-1 \mathrm{Mo}$ class steels and their many derivatives. What is known from the literature is that the best combination of strength and toughness in these steels can be obtained when they contain bainitic microstructure.

Bainite originally was described as consisting of only two distinguishable microstructures: upper and lower bainite. Upper bainite consists of laths with carbides at the lath boundaries. Lower bainite consists of plates or laths containing arrays of carbides that form at $60^{\circ}$ to the plate axis. These kinds of upper and lower bainites can be categorized as classical bainite. In the 1960s, it was discovered that when certain low-carbon, low-alloy steels were transformed by continuous cooling to ambient temperature (as opposed to an isothermal transformation), the morphology of the bainite microstructure that formed was different from the classical upper and lower bainites [1]. Two types of "nonclassical" bainite were identified: carbide-free acicular and granular bainite (the names being descriptive of the microstructures). Which microstructure formed depended on the cooling rate from the austenitization temperature. In particular, it was shown that the continuous-cooling transformation diagram could be partitioned into three zones to represent the different transformation products.

- Carbide-free acicular bainite formed when the steel was cooled above some critical rate.

- Below this rate, granular bainite formed.

- A still slower cooling rate produced ferrite, which is to be avoided for high-strength steel.

Even though the microstructures produced by continuous cooling are extremely important because continuous cooling is used in steel manufacturing, very little work has been done on the fracture toughness/strength and the toughening/strengthening mechanisms of the nonclassical bainite microstructures. As a result, knowledge about producing high-fracture toughness/strength bainitic steels through their toughening/strengthening mechanisms is lacking.

In work at ORNL from 1985 to 1990 under the U.S. Department of Energy's (DOE's) Fossil Energy and Fusion Materials Programs, it was discovered that the impact toughness of bainite in $3 \mathrm{Cr}-1.5 \mathrm{MoV}$ [2] and 2Cr-2WV [3] steels, as measured by a Charpy-impact test, depended on how rapidly the steel was cooled through the bainite transformation regime after the austenitization treatment: the faster the cooling rate the better the properties [4,5]. Microstructural studies indicated that improved strength and toughness were associated with acicular bainite, and poorer strength and toughness with granular bainite.

Granular bainite consists of equiaxed grains of low-carbon bainite with martensite-austenite (M-A) islands [1-3]. During cooling, carbon is rejected by the bainite into the untransformed austenite. The pockets of high-carbon austenite that remain when most of the steel has been transformed have a lower transformation temperature. Therefore, part of the remaining austenite transforms to martensite, and the rest is retained as austenite - the M-A islands. When the steel is tempered, carbon precipitates in the high-carbon M-A islands form large globular carbides. These brittle carbides act as crack nuclei that cause the reduced toughness in the granular bainite. No such large carbides form in the uniform acicular bainite microstructure when it is tempered. This effect of different bainite microstructures on fracture toughness and on the crack resistance mechanism has never been investigated [3] and has thus not been used to produce high-fracture-toughness alloys for the steel industry. 
Steel's hardenability is a measure of its relative ability to avoid the formation of ferrite and form martensite or bainite. As the hardenability increases, the start of the ferrite transformation is progressively delayed, thus allowing the steel to cool more slowly and still form bainite or martensite. Hardenability can be changed by changing the chemical composition. In work at ORNL, it was concluded that by increasing hardenability, it should be possible to cool a steel more slowly or, more importantly, cool larger sections and still obtain the favorable acicular bainite $[3,4]$. This was demonstrated by adding chromium and tungsten to increase the hardenability of $2.25 \mathrm{Cr}$ steels of different compositions, work that led to a patent [5] for steels based on Fe-3Cr-3W-0.25V-0.1C $(3 \mathrm{Cr}-3 \mathrm{WV})$.

The most widely used piping steel in the power generation and the chemical and petrochemical industries is $2 \mathrm{Cr}-1 \mathrm{Mo}$ steel (nominally Fe-2.25Cr-1Mo-0.1C), a steel with quite low strength. For applications requiring higher strength, high-chromium steels, such as modified $9 \mathrm{Cr}-1 \mathrm{Mo}$ (nominally Fe-9Cr-1Mo-0.2V-0.07Nb-0.05N-0.1C) and Sandvik HT9 (nominally $12 \mathrm{Cr}-1 \mathrm{Mo}-0.25 \mathrm{~V}-0.5 \mathrm{~W}-0.5 \mathrm{Ni}-$ $0.2 \mathrm{C}$ ) [1], are used. The NT $3 \mathrm{Cr}-3 \mathrm{WV}$ steel is much stronger than $2 \mathrm{Cr}-1 \mathrm{Mo}$ steel when tempered at $700^{\circ} \mathrm{C}$ (Fig. 3.1), while still being just as tough [4]. The strength of the $3 \mathrm{Cr}-3 \mathrm{WV}$ steel is comparable to that of modified $9 \mathrm{Cr}-1 \mathrm{Mo}$ and Sandvik HT9 steels when all three steels are tempered at $750^{\circ} \mathrm{C}$. However, these commercial 9 and $12 \mathrm{Cr}$ steels are given a standard temper at 760 and $780^{\circ} \mathrm{C}$, respectively, to achieve sufficient toughness, thus further enhancing the strength advantage of the $3 \mathrm{Cr}-3 \mathrm{WV}$ steel. At present, two Japanese-developed steels-T23 (nominally $2.5 \mathrm{Cr}-1.6 \mathrm{~W}-0.15 \mathrm{Mo}-$ $0.25 \mathrm{~V}-0.05 \mathrm{Nb}-0.003 \mathrm{~B}-0.07 \mathrm{C})$ and T2 4 (2.4Cr-1 Mo-0.25V-0.004B-0.08C) - are on the market to replace $2 \mathrm{Cr}-1 \mathrm{Mo}$. Figure 3.1 shows the yield stress of T24, the stronger of the two steels, in its standard NT (tempered at $750^{\circ} \mathrm{C}$ ) condition [6]. Obviously, the new class of Fe-3Cr-W(V) steel has a decided advantage if it can be tempered at $700^{\circ} \mathrm{C}$ or if, as discussed below, it can be used in the untempered condition. In addition to high strength, it appears that $3 \mathrm{Cr}-3 \mathrm{WV}$ steel can be tempered at temperatures as low as $700^{\circ} \mathrm{C}$ and still retain excellent toughness, thus giving this new steel a decided advantage in strength with the same toughness [3].

Ideally, a steel would develop high toughness with little or no tempering, thus avoiding sacrificing strength for improved toughness. Steel structures are fabricated by welding, after which most steels require PWHT similar to the tempering treatment. PWHT tempers the structure transformed during weld solidification and relieves stresses due to volume changes during solidification. An ideal bainitic steel could be used without a temper and without PWHT. Development of such steel is a goal of the steel industry. However, researchers and industry lack an understanding of the relationship between fracture toughness/crack resistance and the microstructure distribution in the fusion zone and HAZ. There is a cooling rate gradient in the fusion zone and the HAZ where the bainite structure and the carbides type and size distribution will be different.

If a new class of bainitic $\mathrm{Cr}-\mathrm{W}$ steels were to be successfully developed, they would have economic advantages over the steels now being used:

- They would use less of the expensive alloying element chromium than do the high-chromium (9 and $12 \mathrm{Cr}$ ) steels they would replace.

- They would have lower production and fabrication costs by eliminating the need for tempering and PWHT

- Less steel (smaller wall thickness and section sizes) would be required for a structure because of the material's higher strength.

- Given the possibility that chromium supplies could be uncertain in the future, lowerchromium steel would also conserve a strategic material. 



Fig. 3.1. Microstructures of (a) normalized and (b) normalized-and-tempered $3 \mathrm{Cr}-3 \mathrm{WV}$ steels.

At present, relatively little information beyond that summarized above is available for the steels. The full potential for application of these steels will require a complete understanding of how to control the composition and heat treatment to achieve high strength and toughness. That is the subject of this report.

The approach for the project described in this report consisted of the following steps:

1. Characterize in detail the microstructure of base alloy compositions Fe-3Cr-3WV and Fe$3 \mathrm{Cr}-3 \mathrm{WV}(\mathrm{Ta})$ in both $\mathrm{N}$ and NT conditions. The plates for this portion of the project were supplied by ORNL. The microstructural characterization focused on characterizing the bainitic structure in detail as well as the formation of carbides at the grain boundary and in the matrix.

2. Determine the fracture toughness $\left(\mathrm{K}_{\mathrm{IC}}\right)$ of the base alloy in $\mathrm{N}$ and $\mathrm{NT}$ conditions. The plates for this testing were supplied by ORNL. These tests focused on obtaining data that would show the effect of tempering treatment and composition on $\mathrm{K}_{\mathrm{IC}}$ values.

3. Determine the $\mathrm{K}_{\mathrm{IC}}$ fracture toughness for welded plates of the final alloy composition developed for commercial applications. $\mathrm{K}_{\mathrm{IC}}$ values were determined for the base metal and HAZ of a GTA-welded plate 1 in. thick. This plate was welded at ORNL and supplied to the University of Pittsburgh in the as-welded condition. The $\mathrm{K}_{\mathrm{IC}}$ values for the HAZ were measured in both as-welded and PWHT conditions. 



\section{Results and Discussion}

\subsection{Experimental Procedure}

The chemical compositions of the $3 \mathrm{Cr} 3 \mathrm{WV}$ and $3 \mathrm{Cr} 3 \mathrm{WVTa}$ steels used in this study are given in Table 4.1. Specimens were obtained from N and NT 30-mm-thick plates. The steel plates were normalized by austenitization for $1 \mathrm{~h}$ at $1100^{\circ} \mathrm{C}$ to ensure that the vanadium carbide dissolved during austenitization and then were air-cooled. After normalizaiton, the steels were tempered for $1 \mathrm{~h}$ at $700^{\circ} \mathrm{C}$. The microstructures of the steels were studied by means of optical microscopy (OM) and analytic electron microscopy. Both the foil specimens and the extraction replicas were examined by transmission electron microscopy (TEM). The TEM analysis was performed on a JEOL 200C electron microscope equipped with an energy-dispersive X-ray (EDX) spectrometer. Extraction replicas on carbon-coated copper grids were used for precipitate analysis to avoid matrix effects in obtaining EDX spectra. Precipitates were identified by a combination of electron diffraction and EDX analysis.

Tensile and fracture toughness tests were carried out at room temperature. Tensile specimens were taken transverse to the rolling direction with gage sections $6.3 \mathrm{~mm}$ in diameter by $25 \mathrm{~mm}$ long. Tests were performed according to specification ASTM E8. For fracture toughness tests, compact tension (CT) specimens were used for measurement of fracture toughness, $K_{I C}$, according to specification ASTM E399. All of the test specimens were taken transverse to the rolling direction, with cracks propagating in the longitudinal (rolling) direction. The specimens ( $W=50 \mathrm{~mm}$ and $B=25 \mathrm{~mm})$ were precracked by fatigue to a nominal crack length of $a / W=0.59$. After the $K_{l C}$ test, the provisional stress intensity factors were obtained on the basis of recorded load-load line-displacement curves. These provisional stress intensity factors were then incorporated into the specimen size requirements to determine where preliminary specimen dimensions are able to yield a specimen that conforms to the size requirements. Scanning electron microscopy (SEM) was also employed to observe the fractured surface of the steels after $K_{l C}$ tests.

Table 4.1. Chemical composition of 3 Cr3WV and 3 Cr3WVTa steels (wt \%)

\begin{tabular}{lccccccccc}
\hline \multicolumn{1}{c}{ Steel } & $\mathbf{C}$ & $\mathbf{S i}$ & $\mathbf{M n}$ & $\mathbf{P}$ & $\mathbf{S}$ & $\mathbf{C r}$ & $\mathbf{W}$ & $\mathbf{V}$ & $\mathbf{T a}$ \\
\hline 3Cr3WV & 0.097 & 0.14 & 0.50 & 0.005 & 0.004 & 2.96 & 2.85 & 0.25 & \\
3Cr3WVTa & 0.097 & 0.14 & 0.50 & 0.005 & 0.004 & 2.94 & 2.85 & 0.25 & 0.10 \\
\hline
\end{tabular}

\subsection{Optical and TEM Analysis of Microstructure}

The typical microstructures of the N and NT 3Cr-3WV steels are shown in Fig. 3.1. Acicular structures containing no polygonal ferrite were observed after both the $\mathrm{N}$ and the NT treatments. These structures were considered to be $100 \%$ bainite. Figure 4.1 shows the microstructures of bainite in $3 \mathrm{Cr}-3 \mathrm{WVTa}$ steels. When the microstructures of $3 \mathrm{Cr}-3 \mathrm{WV}$ and $3 \mathrm{Cr}-3 \mathrm{WVTa}$ are compared under $\mathrm{N}$ and NT conditions, the major difference in the bainite of these steels is that $3 \mathrm{Cr}-3 \mathrm{WVTa}$ has a much finer prior austenite grain size, as shown in Fig. 4.1. This result is consistent with the previous study by R. L. Klueh et al. [7], who found that martensite 9Cr-2WVTa steel had a much smaller prior austenite grain size than did $9 \mathrm{Cr}-2 \mathrm{WV}$ steel [8]. These results indicated that tantalum can decrease the prior austenite grain size and behaves like niobium. 
TEM was used to study the microstructure in these steels. Both foil and replica specimens were examined, with the replicas providing the best method for studying the complex carbides that were present. From an examination of foil specimens, it was found that the N $3 \mathrm{Cr}-3 \mathrm{WV}$ steel contained carbide-free acicular bainite with high dislocation density, as shown in Fig. 4.2(a). However, dark regions, or "islands," also occurred in limited areas. These "islands" were usually present in the N steels when granular bainite was formed [9]. A high dislocation density was still evident in the NT specimen even though the steel had been tempered for $1 \mathrm{~h}$ at $700^{\circ} \mathrm{C}$ [Fig. 4.2(b)]. However, there was clear evidence of the formation of a cellular structure that maintained the lath morphology of acicular bainite. After tempering, precipitates could be detected mainly at the grain boundaries and the subgrain boundaries in the NT specimen.

Figure 4.3 shows TEM micrographs of the microstructures of N and NT 3Cr-3WVTa foil specimens. The results indicated that $3 \mathrm{Cr}-3 \mathrm{WVTa}$ steel also contained acicular bainite where the lath microstructures were well developed. However, the lath size was finer than that formed in $3 \mathrm{Cr}-3 \mathrm{WV}$ steel (Fig. 4.2). Because the laths in the NT 3Cr-3WVTa steel contained a high dislocation density, only occasional precipitates were observed, some in the matrix and others in grain boundaries.
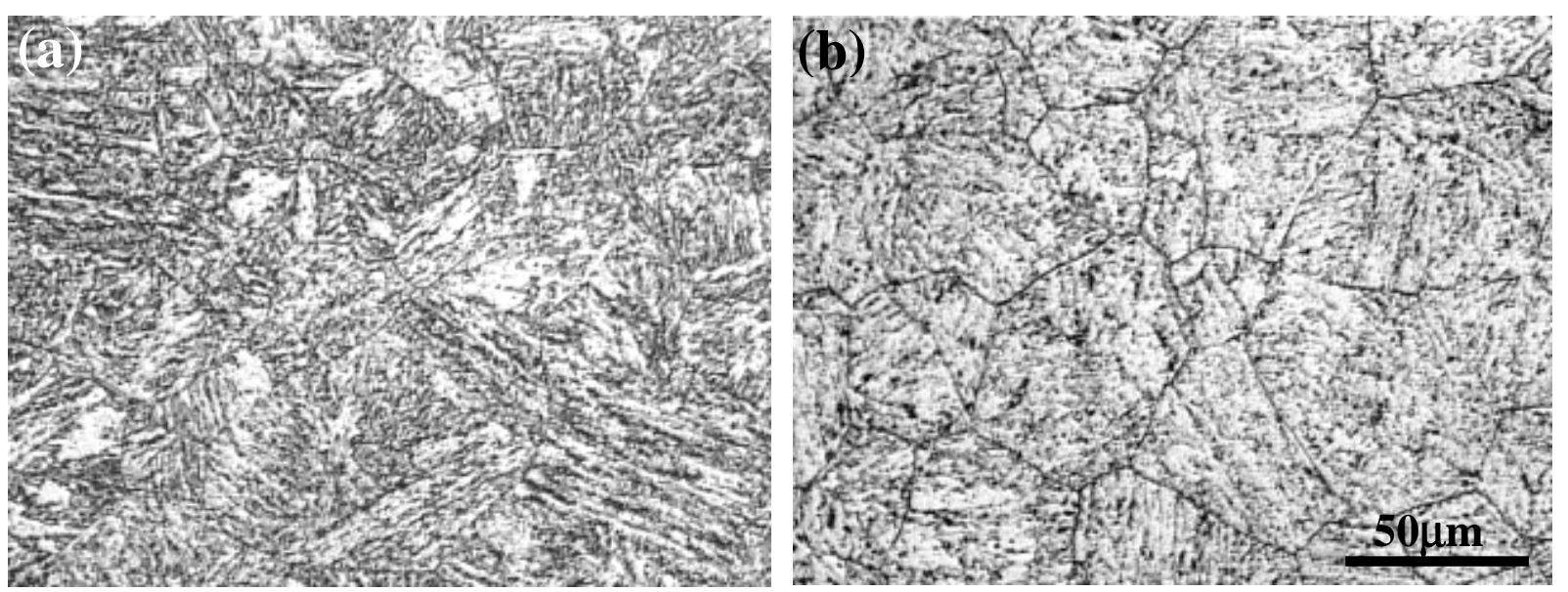

Fig. 4.1. Microstructure of (a) normalized and (b) normalized and tempered $3 \mathrm{Cr}-3 \mathrm{WVTa}$ steels.


Fig. 4.2. Transmission electron photomicrographs of the bainite microstructure of $3 \mathrm{Cr}-3 \mathrm{WV}$ steel: (a) normalized and (b) normalized and tempered. 
The structure of the precipitates in the specimens was examined in more detail on carbide extraction replicas. Figure 4.4 shows micrographs of extraction replicas of $\mathrm{N}$ and NT $3 \mathrm{Cr}-3 \mathrm{WV}$ specimens. No visible precipitates could be found within the $\mathrm{N}$ specimen [Fig. 4.4(a)]. After tempering for $1 \mathrm{~h}$ at $700^{\circ} \mathrm{C}$, however, a high density of precipitates was evident. Coarse, iron-rich $\mathrm{M}_{23} \mathrm{C}_{6}$ or $\mathrm{M}_{3} \mathrm{C}$ carbides (up to a few hundred nanometers) containing varying amount of $\mathrm{Cr}, \mathrm{W}$, and $\mathrm{V}$ were observed around prior austenite grain boundaries [Fig. 4.4(b)]. Furthermore, agglomerations of globular precipitates were seen in some regions. The same iron-rich carbides and some chromium-rich $\mathrm{M}_{7} \mathrm{C}_{3}$ carbides containing varying amount of $\mathrm{Fe}, \mathrm{W}$, and $\mathrm{V}$ also occurred randomly within the grain interiors. These carbides were typically $\sim 100 \mathrm{~nm}$ in size.

In contrast to the findings with the $3 \mathrm{Cr}-3 \mathrm{WV}$ steel, the $\mathrm{N}$ specimen for $3 \mathrm{Cr}-3 \mathrm{WVTa}$ steel contained fine precipitates ranging from 40 to $80 \mathrm{~nm}$ in size, some in prior austenite grain boundaries and others in the matrix, as shown in Fig. 4.5(a). These precipitates were tantalum-rich carbides containing small amounts of iron and chromium. This is illustrated by the EDX spectrum shown in Fig. 4.6(a). Microbeams of the diffraction patterns in selected areas proved that the tantalum-rich carbide exhibits a cubic (face center cubic) structure [Fig. 4.6(b)]. Accordingly, the tantalum-rich carbides can be
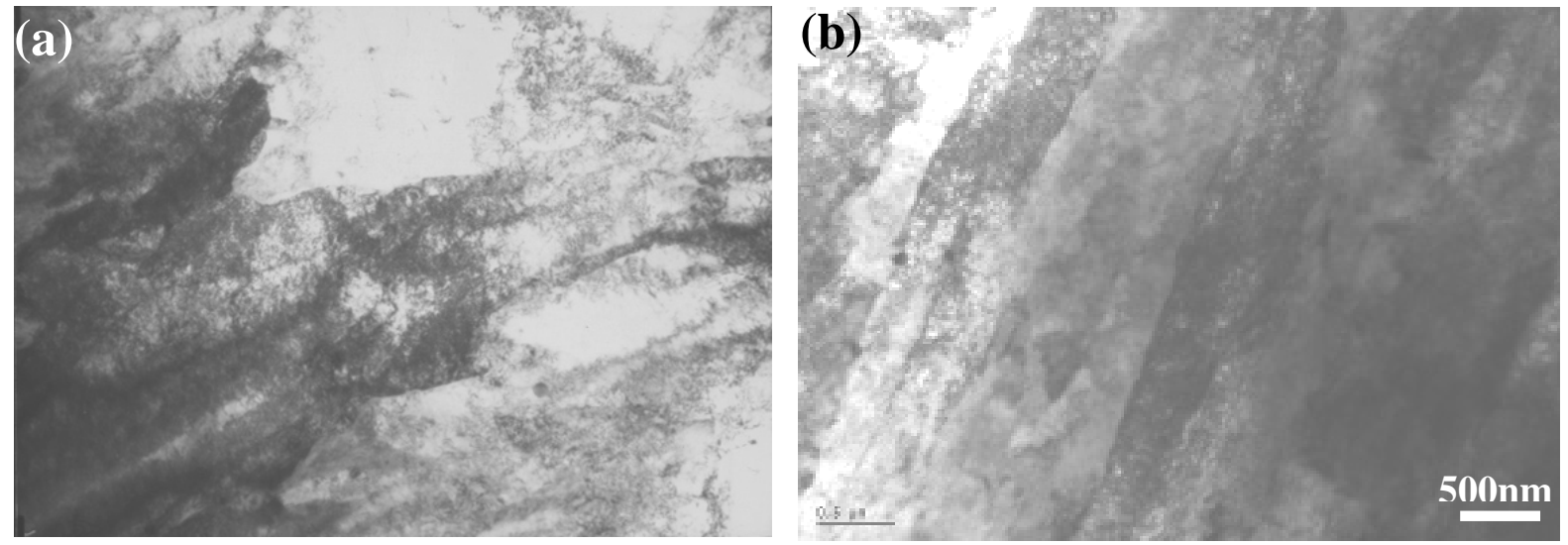

Fig. 4.3. Transmission electron photomicrographs of the bainite microstructure of $3 \mathrm{Cr}-3 \mathrm{WVTa}$ steel: (a) normalized; (b) normalized and tempered.


Fig. 4.4. Transmission electron microscopy micrographs of extraction replicas of (a) normalized $3 \mathrm{Cr}-3 \mathrm{WV}$ steel and (b) normalized and tempered $3 \mathrm{Cr}-3 \mathrm{WV}$ steel. Arrows indicate prior austenite grain boundaries. 

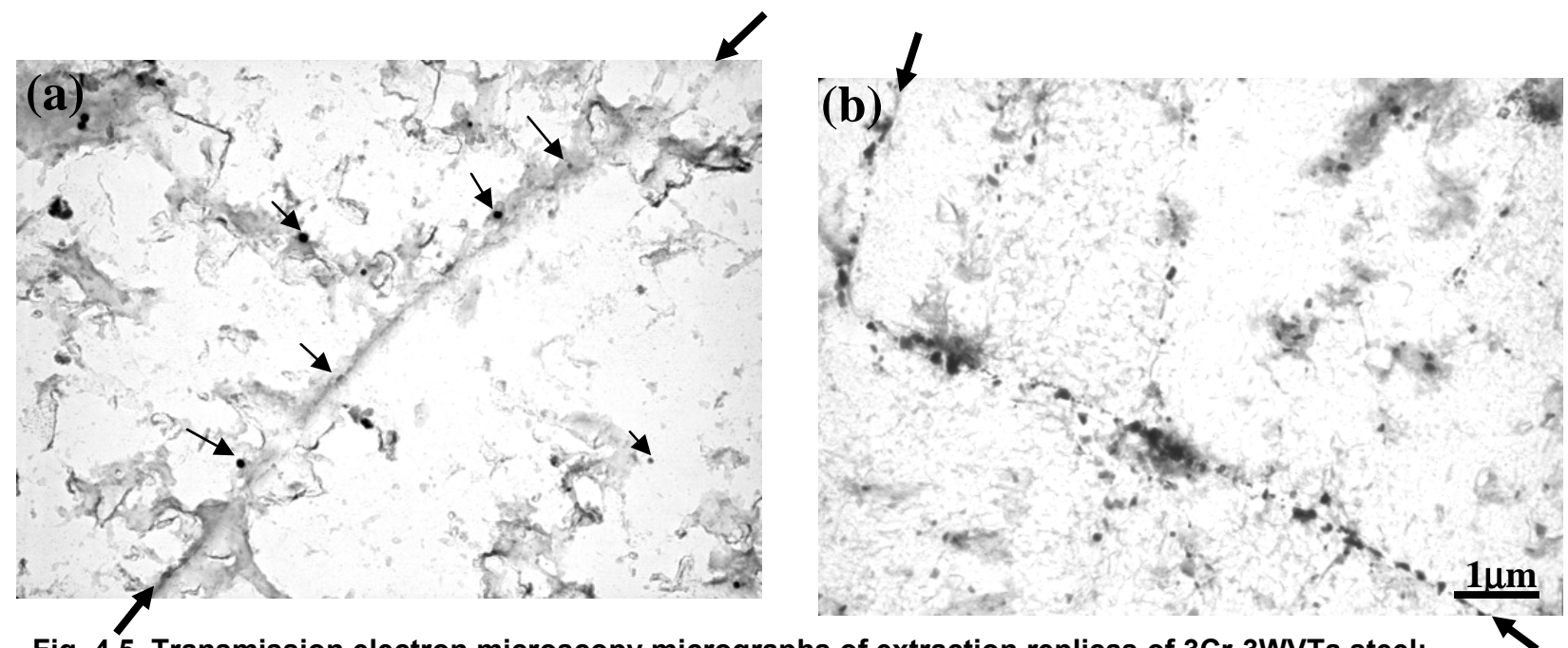

Fig. 4.5. Transmission electron microscopy micrographs of extraction replicas of 3Cr-3WVTa steel: (a) normalized and (b) normalized and tempered. Prior austenite grain boundaries and TaC carbides are indicated by large and small arrows, respectively.
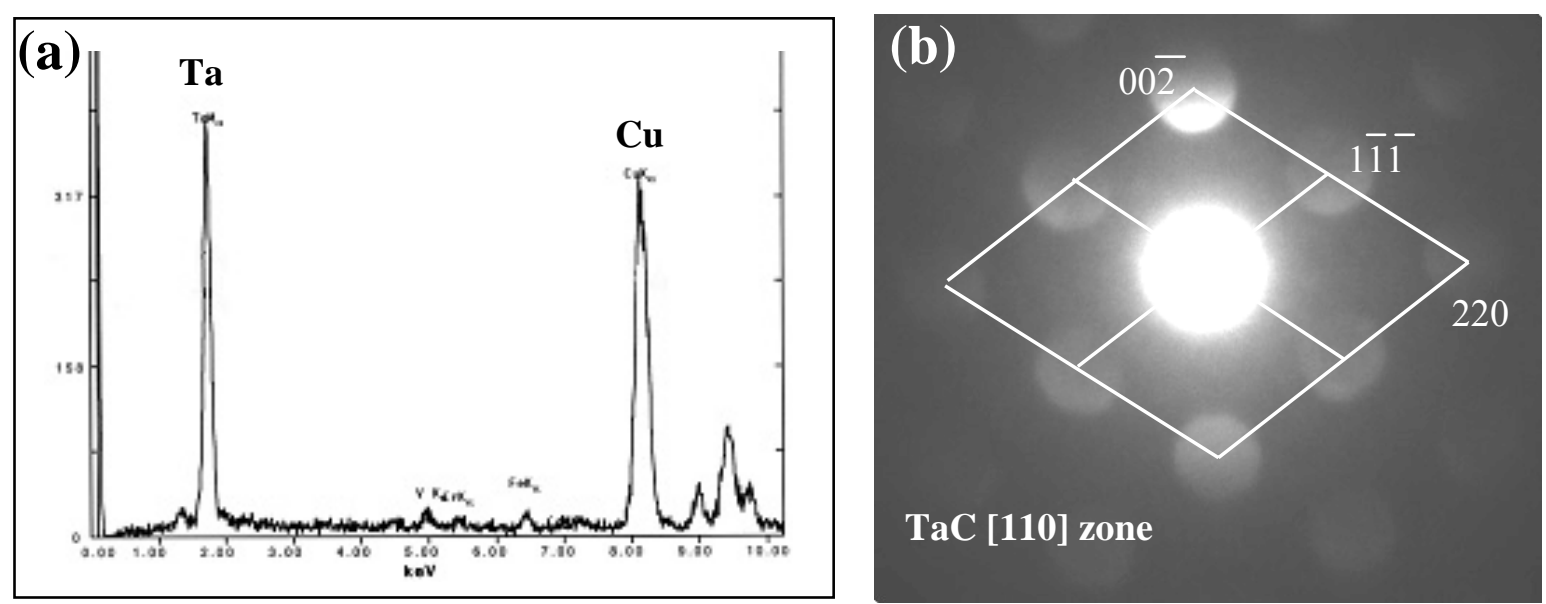

Fig. 4.6. Energy dispersive $X$-ray spectrum and microbeam diffraction pattern of particles shown in Fig 4.5: (a) Energy dispersive spectrum of tantalum-rich carbide [indicated in Fig. 4.5(a) by small arrows]. (b) Microbeam diffraction pattern of TaC.

as $\mathrm{TaC}[10]$. After tempering, the density of fine precipitates (including tantalum- and iron-rich carbides and some chromium-rich $\mathrm{M}_{7} \mathrm{C}_{3}$ carbides) within the grains was increased, as shown in Fig. 4.7. Furthermore, in contrast to $3 \mathrm{Cr}-3 \mathrm{WV}$ steel, the precipitates in grain boundaries did not obviously coarsen [Fig. 4.5(b)].

Table 4.2 lists microstructure parameters typically associated with OM and TEM observations for these steels. It is notable that in these two steels the difference in the average diameter of the bainite packet [11] was much smaller than the prior austenite grain size. The steel containing tantalum had a significantly finer prior austenite grain size and a smaller lath size than did the $3 \mathrm{Cr}-3 \mathrm{WV}$ steel (Table 4.2). Jayaram et al. also found that tantalum had these effects in 9Cr-2WV(Ta) steels [12], even though the tantalum content was very low $(\sim 0.02 \%)$ in their study. In addition, these researchers found that most of the tantalum was in solid solution even after the tantalum-containing steel was tempered for $1 \mathrm{~h}$ at $750^{\circ} \mathrm{C}$. Therefore, they inferred that some small fraction could segregate to grain boundaries and thereby provide a mechanism for grain refinement. The results of the current study 
showed that the 3Cr-3WVTa steel contained a small amount of $\mathrm{TaC}$ after normalizing [Fig. 4.5(a)]. The model of Nawrocki and associates indicated that $\mathrm{NbC}(>25 \mathrm{~nm})$ could not be dissolved at $1100^{\circ} \mathrm{C}$ in the HCM2S steels [13]. Because TaC is more thermodynamically stable than $\mathrm{NbC}$ [14], it is reasonable to assume that some $\mathrm{TaC}$ particles remain in the austenite grain boundaries in the steel during normalization at $1100^{\circ} \mathrm{C}$. It can be assumed that these $\mathrm{TaC}$ particles arrested the growth of the austenite grains, resulting in a finer austenite grain size in the tantalum steel. The effects of tantalum on the bainite microstructure and carbides are discussed in the following sections.

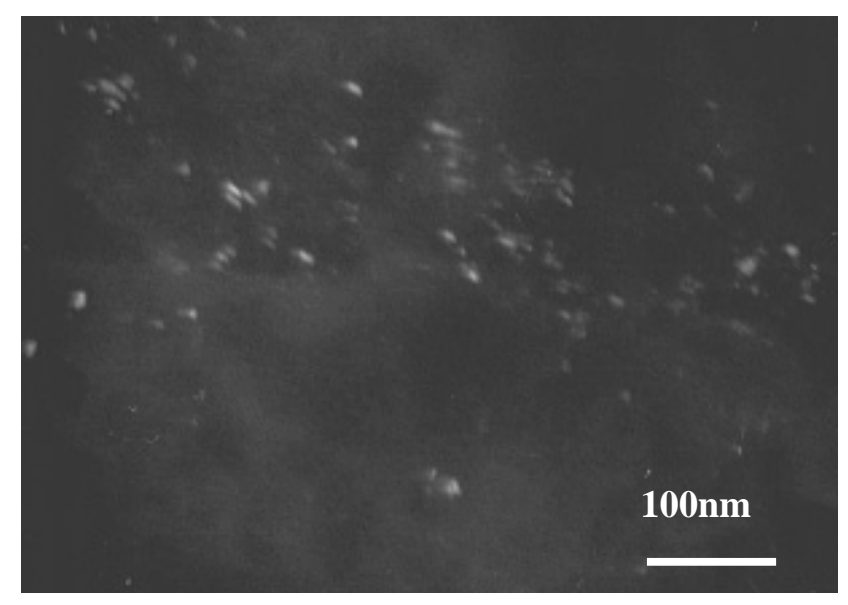

Fig. 4.7. Transmission electron microscopy dark-field image of extraction replica showing fine carbides formed in normalized and tempered 3Cr-3WVTa steel.

Table 4.2. Typical microstructural parameters of the $3 \mathrm{Cr}-3 \mathrm{WV}$ and $3 \mathrm{Cr}-3 \mathrm{WVTa}$ steel (sizes in $\mu \mathrm{m}$ )

\begin{tabular}{cccccc}
\hline Steel & $\begin{array}{c}\text { Heat } \\
\text { treatment }^{\text {a }}\end{array}$ & $\begin{array}{c}\text { Av. grain } \\
\text { diam. }\end{array}$ & $\begin{array}{c}\text { Av. bainite } \\
\text { packet diam. }\end{array}$ & Lath size & $\begin{array}{c}\text { Precipitate } \\
\text { size }\end{array}$ \\
\hline 3Cr-3WV & $\mathrm{N}$ & 58 & 18 & $0.4-0.7$ & - \\
& $\mathrm{N} \& \mathrm{~T}$ & 62 & 20 & $0.5-0.8$ & $0.04-0.50$ \\
$3 \mathrm{Cr}-3 \mathrm{WVTa}$ & $\mathrm{N}$ & 35 & 15 & $0.2-0.5$ & $0.01-0.10$ \\
& $\mathrm{~N} \& \mathrm{~T}$ & 38 & 16 & $0.2-0.6$ & $0.01-0.25$ \\
\hline
\end{tabular}

${ }^{a} \mathrm{~N}=$ normalized; $\mathrm{N} \& \mathrm{~T}=$ normalized and tempered

\subsection{Tensile Strength of the Steels}

The tensile strength and hardness of $3 \mathrm{Cr}-3 \mathrm{WV}$ and $3 \mathrm{Cr}-3 \mathrm{WVTa}$ steels under both the N and the NT conditions are shown in Table 4.3. The results showed that all of the $3 \mathrm{Cr}-3 \mathrm{WV}(\mathrm{Ta})$ steels had strengths as good as or higher than those of the 9Cr-2WV(Ta) steels [14]. The 3Cr-3WVTa steel had relative higher strength than that of $3 \mathrm{Cr}-3 \mathrm{WV}$ under both the $\mathrm{N}$ and NT conditions, especially in the latter case.

Under the $\mathrm{N}$ condition, the addition of tantalum to 3Cr-3WV steel had little effect on its strength. Since only limited $\mathrm{TaC}$ formed within the $3 \mathrm{Cr}-3 \mathrm{WVTa}$ steel after normalization, it is probable that most of the tantalum was in solid solution in the steel. This in turn indicated that tantalum in solution had no significant effect on the strength of the material. Moreover, the finer prior austenite grain size in the $3 \mathrm{Cr}-3 \mathrm{WVTa}$ steel would not have contributed to strengthening bainite structure steels. In fact, it has been reported that it is the bainite packet size rather than the prior austenite grain size that affects mechanical properties $[11,15]$. As Table 4.2 shows, the two steels were close in bainite packet size, which would result in about the same strengthening.

After tempering for $1 \mathrm{~h}$ at $700^{\circ} \mathrm{C}$, both steels exhibited secondary hardening and strengthening behavior. But while there was a large increase in strength after tempering for $3 \mathrm{Cr}-3 \mathrm{WVTa}$ steel, there 
Table 4.3. Strength and fracture toughness of the $3 \mathrm{Cr} 3 \mathrm{WV}$ and $3 \mathrm{Cr} 3 \mathrm{WVTa}$ steels

\begin{tabular}{|c|c|c|c|c|}
\hline Steel & Heat treatment ${ }^{*}$ & $\begin{array}{c}\text { Yield } \\
\text { stress } \\
\text { (MPa) }\end{array}$ & $\begin{array}{l}\text { Hardness } \\
\text { (HV, 500g) }\end{array}$ & $\begin{array}{l}\text { Fracture toughness, } K_{1 C} \\
\text { (MPa.m1/2) }\end{array}$ \\
\hline \multirow[t]{2}{*}{$3 \mathrm{Cr}-3 \mathrm{WV}$} & $\mathrm{N}$ & 814 & 353 & 66.99 \\
\hline & $N \& T$ & 821 & 365 & 73.92 \\
\hline \multirow[t]{2}{*}{ 3Cr-3WVTa } & $\mathrm{N}$ & 818 & 356 & 68.42 \\
\hline & $N \& T$ & 925 & 397 & 78.03 \\
\hline
\end{tabular}

${ }^{a} \mathrm{~N}=$ normalized; N\&T = normalized and tempered

was only a small increase for 3Cr-3WV steel. This difference in strengthening between two steels should be related to the precipitation of carbides during tempering.

The microstructure of 3Cr-3WV steel was bainitic on visible carbides after normalizing [Fig. 4.4(a)]. During tempering at $700^{\circ} \mathrm{C}$, the dissolved carbon precipitated in the form of carbides, both intragranularly and along prior austenite grain boundaries [Fig. 4.4(b)]. The softening due to dislocation recovery and the relaxation of lattice strain was offset by the strengthening due to precipitation of the carbides. However, most of the prior austenite grain boundaries were completely covered by coarse carbides, and carbides within the grain interiors were relative larger. This resulted in limited precipitation-strengthening.

Because of its thermodynamic stability [10], tantalum is the most potent and stable carbide precipitation-strengthening element in the present steels. As can be seen in Fig. 4.5(a), in the N 3Cr-3WVTa steel, TaC had formed both at prior austenite grain boundaries and within the grains. Because a tantalum atom can combine with a carbon atom to form $\mathrm{TaC}$, a portion of the carbon has been released from the matrix before tempering. During tempering, along with the same precipitation of iron- and chromium-rich carbides that was seen with the 3Cr-3WV steel, fine carbides continued to form, mainly within the grains (Fig. 4.7). On the other hand, carbides at prior austenite grain boundaries were much smaller than those in the $3 \mathrm{Cr}-3 \mathrm{WV}$ steel and separated [did not completely cover the grain boundaries, as can be seen in Fig. 4.5(b)]. This was because a part of carbon is tied up in $\mathrm{TaC}$ formation. The additional intragranular precipitation of fine $\mathrm{TaC}$ and smaller carbides at prior austenite grain boundaries in the 3Cr-3WVTa steel resulted in higher strength for this alloy than for the $3 \mathrm{Cr}-3 \mathrm{WV}$ steel.

\subsection{Fracture Toughness and SEM Fractographs}

The fracture toughness values, $K_{I C}$, of $3 \mathrm{Cr}-3 \mathrm{WV}$ and $3 \mathrm{Cr}-3 \mathrm{WVTa}$ steels were relatively close under both $\mathrm{N}$ and NT conditions (Table 4.3). It can be seen, however, that NT 3Cr-3WVTa steel not only had the highest strength (about $100 \mathrm{MPa}$ higher) than the steels lacking tantalum but also relatively higher fracture toughness.

After fracture toughness tests, SEM was used to observe the fracture surface in order to investigate the fracture mechanism. Figure 4.8 shows SEM fractographs of the N 3Cr-3WV and 3Cr-3WVTa steels. The 3Cr-3WV steel exhibited transgranular cleavage fracture [Fig. 4.8(a)]. In addition, some secondary cracks could be observed near the crack tip, indicating the relative brittleness of the steel. On the other hand, 3Cr-3WVTa steel exhibited quasi-cleavage fracture, as demonstrated in Fig.4.8(b). Those observations proved that the toughness of 3Cr-3WV steel has been improved by addition of tantalum into the steel under the normalizing condition. Figure 4.9 shows SEM fractographs of the NT 3Cr-3WV and 3Cr-3WVTa steels, which had comparatively higher fracture toughness values 


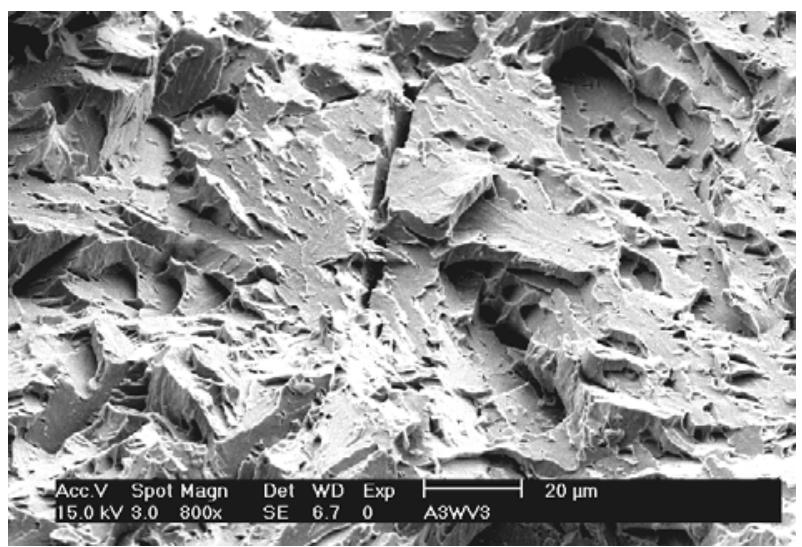

(a)

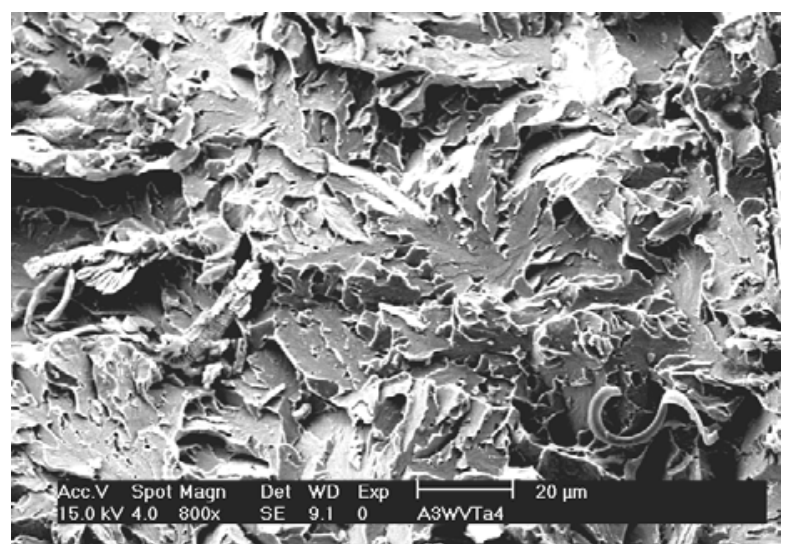

(b)

Fig. 4.8. Scanning electron microscopy fractographs of (a) normalized $3 \mathrm{Cr}-3 \mathrm{WV}$ steel and (b) normalized 3Cr-3WVTa steel.



(a)

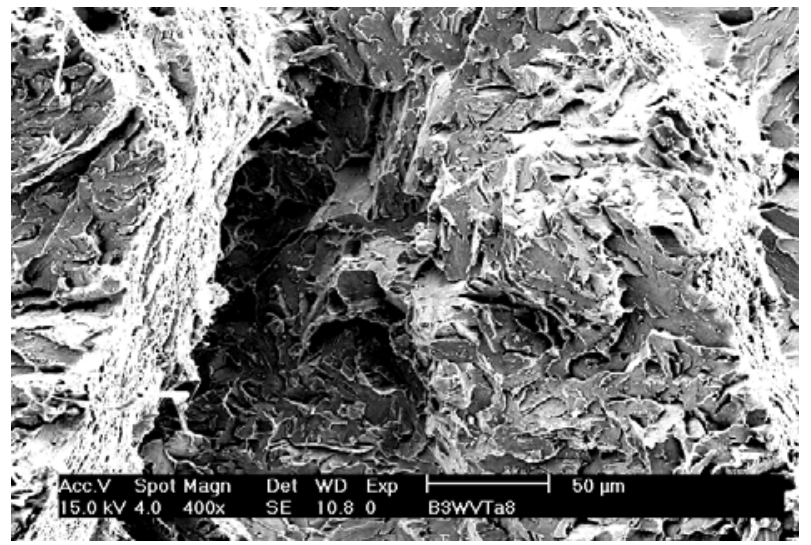

(b)

Fig. 4.9. Scanning electron microscopy fractographs of normalized and tempered steels: (a) $3 \mathrm{Cr}-3 \mathrm{WV}$ and (b) 3Cr-3WVTa.

than the N 3Cr-3WV and 3Cr-3WVTa steels. It was found that both steels exhibited quasi-cleavage. But the quasi-cleavage fracture facets of the $3 \mathrm{Cr}-3 \mathrm{WVTa}$ steel were relatively smaller than those in the $3 \mathrm{Cr}-3 \mathrm{WV}$ specimen. Moreover, wider tear ridges could be found in the front area of the crack tip in 3Cr-3WVTa steel.

The fracture toughness results and microscopic observations of the fractured surfaces indicated that the addition of tantalum could improve the fracture toughness of 3Cr-3WV steel. Previous results also indicated that tantalum could increase upper-shelf energy (USE) and decrease the ductile-brittle transition temperature (DBTT), especially the latter, in the NT (5-9) Cr-WV steels [16]. But they did not explain the reasons for the effect of tantalum on the Charpy-impact properties in detail. Jayaram and associates inferred that tantalum in solution increased the fracture stress of 9Cr-2WVTa steel, based on experimental results that $98 \%$ of the tantalum (total $\mathrm{Ta}=0.02 \%$ ) was still in solution after tempering [12].

The current research showed that the addition of tantalum mainly affected the size and distribution of the carbides, as well as the prior austenite grain size. Therefore, we will discuss the fracture toughness 
of the steels based on carbide and grain sizes that affect fracture stress. It has been pointed out that the coarsest carbides present are the most deleterious to toughness [17] because initially fracture usually occurs at the carbide/matrix interface, and the cleavage faces are determined by the bainite packet size. The fracture stress of the material can be estimated by [18]

$$
\sigma_{f}=\left(\frac{8 \mu \gamma}{\pi(1-v) c}\right)^{/ 2}-\frac{k_{y} d^{1 / 2}}{2 \pi c},
$$

where

$$
\begin{aligned}
& \mu=\text { rigidity modulus } \\
& \gamma=\text { surface energy } \\
& \nu=\text { Poisson ratio } \\
& k_{y}=\text { gradient of Hall-Petch relation } \\
& d=\text { effective grain diameter } \\
& c=\text { critical crack size }
\end{aligned}
$$

Equation (4.1) indicates that fracture stress depends on both carbide size and grain size. When the applied tensile stress is above $\sigma_{f}$, the cracks will propagate to fracture. Typical values for steels are $k_{y}=21 \mathrm{~N} / \mathrm{mm}^{3 / 2}[19], \mu=8.39 \times 10^{4} \mathrm{MPa}, v=0.283$ [20], and $\gamma$ was suggested to be 11 to $17 \mathrm{~J} / \mathrm{m}^{2}$ [18]. If we take the surface energy $\gamma=14 \mathrm{~J} / \mathrm{m}^{2}$ [14], the bainite packet sizes of $20 \mu \mathrm{m}$ and $16 \mu \mathrm{m}$ as the effective grain diameters for $3 \mathrm{Cr}-3 \mathrm{WV}$ and $3 \mathrm{Cr}-3 \mathrm{WVTa}$, and the size of the coarsest carbide as the critical crack length $(0.50 \mu \mathrm{m}$ for $3 \mathrm{Cr}-3 \mathrm{WV}$ steel and $0.25 \mu \mathrm{m}$ for $3 \mathrm{Cr}-3 \mathrm{WVTa}$ steel $)$, then we can calculate the fracture stress to be $1943 \mathrm{MPa}$ for NT 3Cr-3WV steel and $2393 \mathrm{MPa}$ for NT 3Cr$3 \mathrm{WVTa}$ steel. These predicated $\sigma_{f}$ values are in the range of measured fracture stress values for bainite steels [16].

At the crack tip in the specimen, yielding occurs in a constrained condition, and the constrained yield stress $\left(\sigma_{y}\right)$ is higher than the uniaxial yield stress $\left(\sigma_{y s}\right)$. If we take 2.5 as the plastic constraint factor (e.g., $\sigma_{y}=2.5 \sigma_{y s}$ ) for the fracture toughness tests under the plane strain condition [13], according to the experimental data for uniaxial yield stress (Table 4.2) the constrained yield stress $2.5 \sigma_{y s}$ of NT 3Cr-3WV and 3Cr-3WVTa steels are $2052 \mathrm{MPa}$ and $2313 \mathrm{MPa}$, respectively. Obviously, the calculated fracture stress, $\sigma_{f}$, for both steels [1943 MPa and $2393 \mathrm{MPa}$ based on Eq. (4.1)] was lower than but close to the constrained yield stress $2.5 \sigma_{y s}(2052 \mathrm{MPa}$ and $2313 \mathrm{MPa})$. Therefore, cracks nucleated from coarse carbides started to propagate before any yielding of the materials occurred during fracture tests, and the steels fractured almost by quasi-cleavage [20]. However, even in the case of the quasi-cleavage process, the fracture toughness of the 3Cr-3WVTa steel was improved over that of the $3 \mathrm{Cr}-3 \mathrm{WV}$ steel because of the higher fracture stress.

Although the addition of tantalum does not significantly improve the fracture toughness of $3 \mathrm{Cr}-3 \mathrm{WV}$ steel at room temperature, a lower DBTT for 3Cr-3WVTa steel can be predicted on the basis of the above results and discussions. As the testing temperature is decreased, $\sigma_{y}$ will increase, while $\sigma_{f}$ will have less change. Because the difference in $\sigma_{f}$ between two steels is much larger than the difference in $\sigma_{y}$, a lower DBTT could be obtained for 3Cr-3WVTa steel (Fig. 4.10). As proved by previous studies, the addition of tantalum into (5-9) Cr-WV steels could remarkably decrease DBTT. The effect on USE was not as significant [16]. 


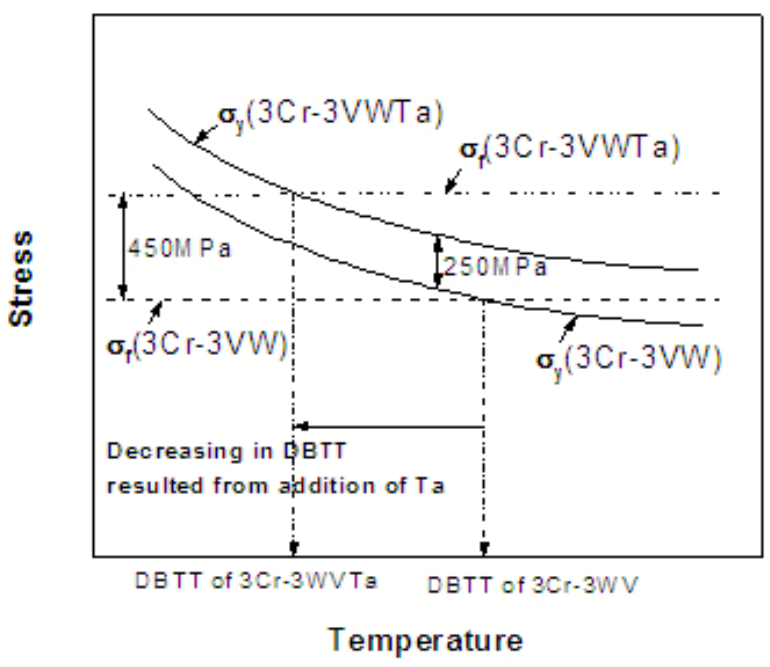

Fig. 4.10. Schematic of difference in ductile-brittle transition temperature (DBTT) between $3 \mathrm{Cr}-3 \mathrm{WV}$ and $3 \mathrm{Cr}-3 \mathrm{WVT}$ a steels.

\subsection{Effect of PWHT on Fracture Toughness and Strength Distribution of Welding Joints}

It has been known that a PWHT similar to the tempering treatment is required for most steels after welding to restore fracture toughness or strength in the welding joint. An ideal bainitic steel would require neither tempering nor PWHT. Such a steel is a goal of the steel industry. The new class of Fe$\mathrm{Cr}-\mathrm{W}(\mathrm{V})$ ferritic steels have the potential to be welded without PWHT. A Fe-Cr-W(V) ferritic steel with the chemical composition shown in Table 4.4 was welded by manual gas tungsten welding.

Table 4.4. Chemical composition of $3 \mathrm{Cr}-2 \mathrm{WV}$ steel (wt \%)

\begin{tabular}{ccccccccc}
\hline $\mathbf{C}$ & $\mathbf{S i}$ & $\mathbf{M n}$ & $\mathbf{P}$ & $\mathbf{S}$ & $\mathbf{C r}$ & $\mathbf{W}$ & $\mathbf{V}$ & Mo \\
\hline 0.099 & 0.21 & 0.34 & 0.009 & 0.003 & 2.97 & 1.68 & 0.22 & 0.73 \\
\hline
\end{tabular}

The microstructures of the base metal, the heat-affected zone (HAZ), and the weld metal were examined by OM and SEM. The microhardness across these regions was determined using a Leco M400-G hardness tester at a load of $500 \mathrm{~g}$. The steel was obtained from N and NT 25-mm-thick plates. The steel plates were normalized by austenitizing them for $1 \mathrm{~h}$ at $1100^{\circ} \mathrm{C}$ to ensure that the vanadium carbide dissolved during austenitization. They were then were air-cooled. After normalizing, the steels were tempered for $1 \mathrm{~h}$ at $700^{\circ} \mathrm{C}$. The plates were welded manually with gas tungsten using 0.045 -in. filler wire (heat no. 25B64-2). The weld opening had an included angle of $60^{\circ}$. The plate was restrained during welding.

As can be seen in Fig. 4.11, the typical microstructure of the base metal is an acicular structure without polygonal ferrite. The average grain size of the bainite was about $56 \mu \mathrm{m}$. A typical 
macrosection of the welded joint is shown in Fig. 4.12. There are 50 weld passes in this weld. The weld was left in the as-welded condition. Fifty passes would create a significant interpass tempering.

Figure 4.13 is a metallograph of the weld joint showing the base metal and HAZ, as well as the weld metal. The thickness of the grain-coarsened $\mathrm{HAZ}$ was about $600 \mu \mathrm{m}$; the microstructure is shown in Fig. 4.14. The average grain size of the coarsened HAZ was estimated to be $97 \mu \mathrm{m}$, much larger than the grain size of the base metal, indicating the growth of austenite grain during welding. The microstructures of the weld metals are shown in Fig. 4.15. The much smaller grain size of the middle weld metals, due to heat treatment following welding, was quite different from the microstructure of the top weld, which was dendritic and contained polygonal ferrites.

Figure 4.16 shows the microhardness measurements across the weld in the as-welded condition. The hardness of the top weld metal was much higher than that of the middle weld metal (which had been tempered by heat treatment after welding) and was also higher than that of the base metal. In contrast, the hardness of

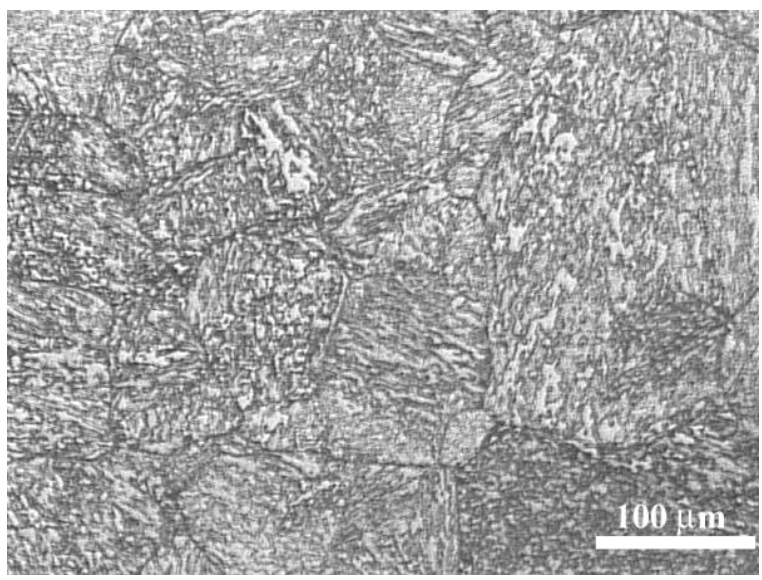

Fig. 4.11. Typical microstructure of base metal, showing acicular bainite without polygonal ferrite.

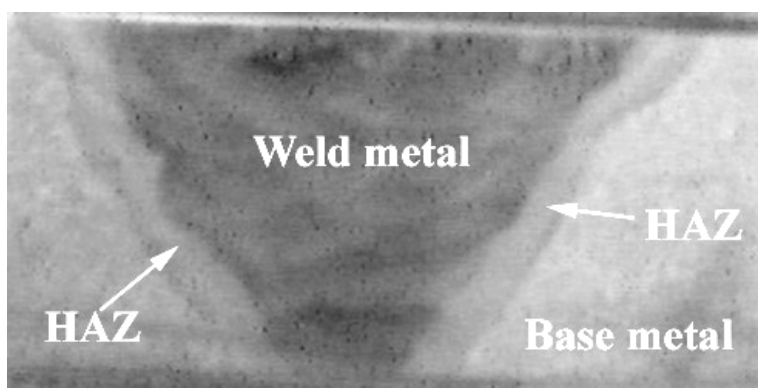

Fig. 4.12. Macrosection of welded joint showing base metal, heat-affected zone (HAZ), and the weld metal. the middle weld was smaller than that of base metal. The grain-coarsened HAZ had highest hardness along the joint. Softening is also noted from traverses, with a maximum hardness decrease of $\sim 10-30 \mathrm{HV}$. Compact tension (CT) specimens taken from the welded samples with and without PWHT (Fig. 4.17) were used to measure fracture toughness, $K_{l C}$, according to ASTM E399. All the CT specimens were machined along the T-L orientation.

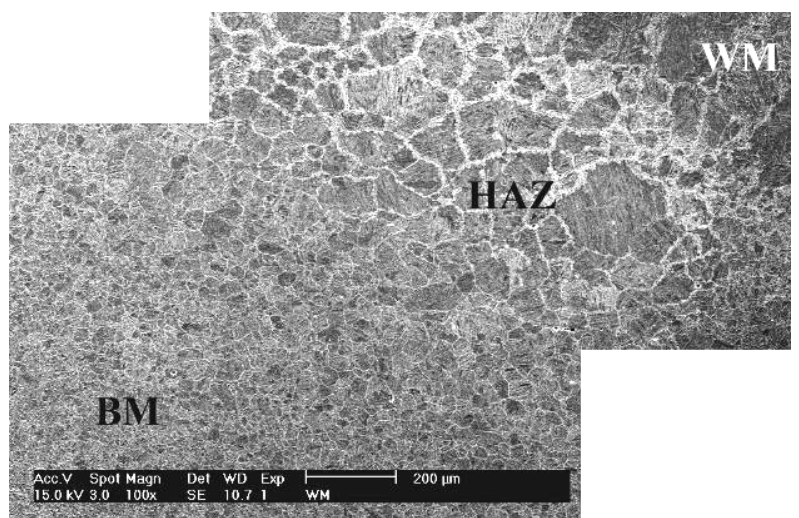

Fig. 4.13. Metallograph of weld joint showing base metal, heat-affected zone, and weld metal.

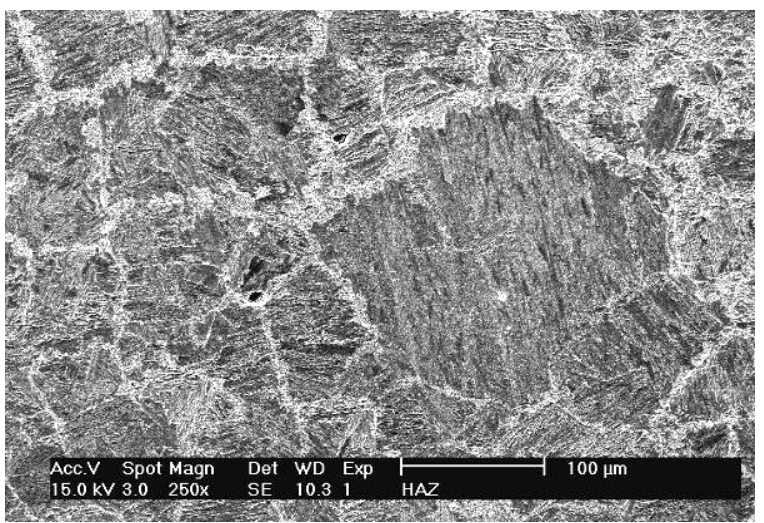

Fig. 4.14. Microstructure of grain-coarsened heataffected zone. 
Table 4.5 shows the mechanical properties of the $3 \mathrm{Cr}-2 \mathrm{WV}$ steel. Figure 4.18 is a graph of the fracture toughness, $K_{I C}$, of the HAZ of the welded joint (with and without PWHT) and that of the base metal. It can be seen that the fracture toughness of HAZ under the as-welded condition was only a little lower than that of the base metal. The fracture toughness of HAZ after PWHT was the same as that without PWHT, under the as-welded condition, indicating that this kind of bainitic steel can be used without tempering and without a PWHT.

After measurements of fracture toughness, the fracture surface of the specimen was observed with SEM in order to clarify the fracture mechanism. Figure 4.19 shows the fractographs of the HAZ specimen. The fracture of HAZ exhibits transgranular quasi-cleavage fracture [Fig. 19(b)]. However, secondary cracks can be observed near the crack tip. Consistent with the decreased variation in fracture toughness, the base metal and weld metal also represent the morphology of quasi-cleavage, but tear ridges in the front of crack tip can be clearly seen [Fig. 4.19(c) and (d)]. The fractographs of the HAZ specimen given PWHT are similar to those without PWHT, as seen in Fig. 4.20.
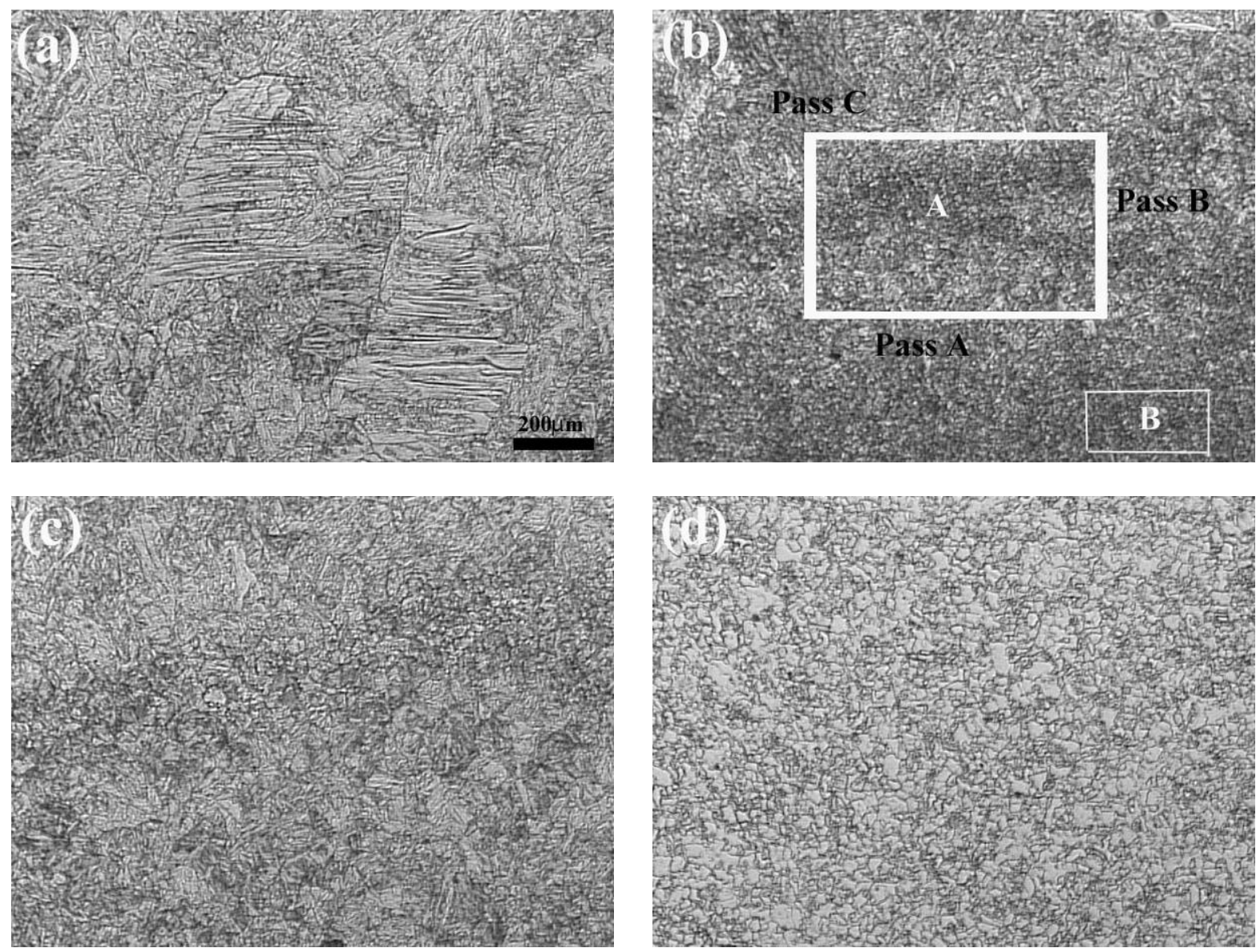

Fig. 4.15. Microstructures of weld metals: (a) top weld; (b) middle weld metal showing passes $A$, B, and C; (c) high magnification of area A in (b); (d) high magnification of area B in (b). 


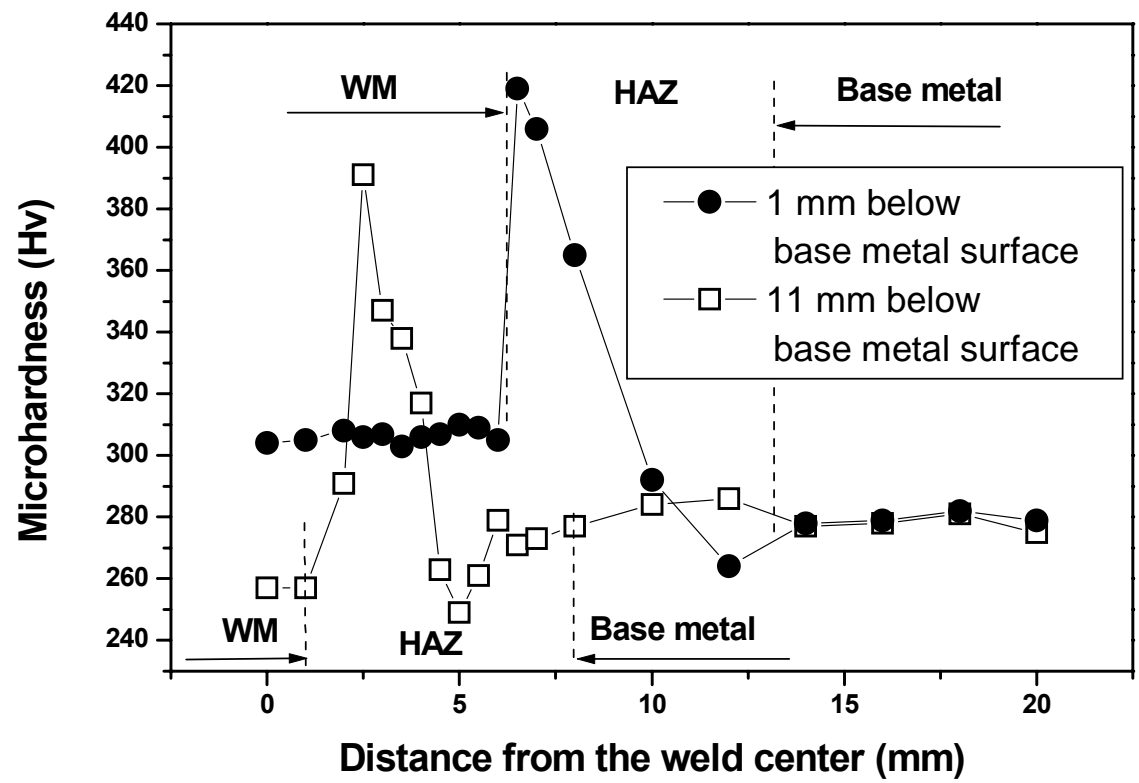

Fig. 4.16. Microhardness measurement results across the weld in the aswelded condition.

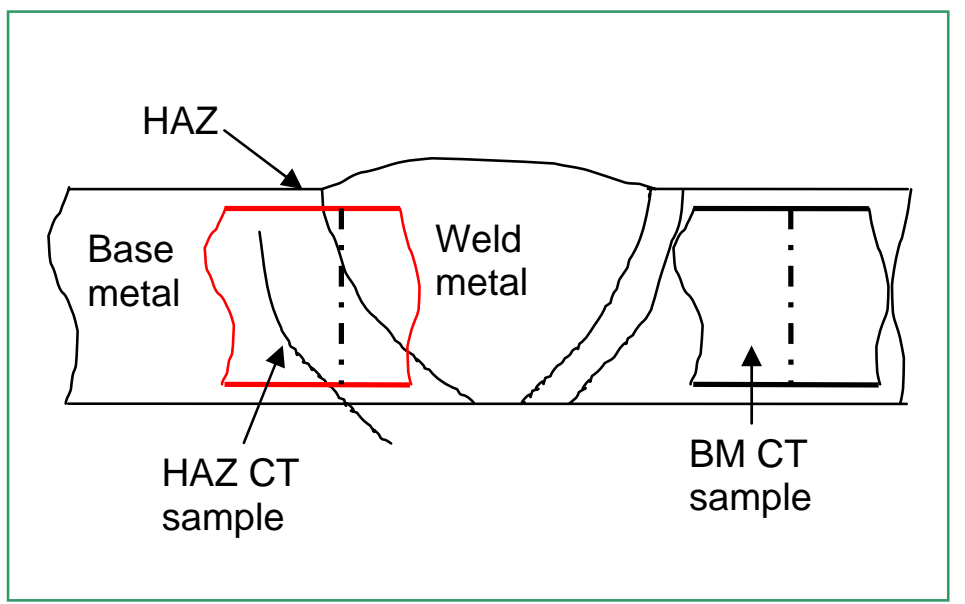

Fig. 4.17. Schematic showing the positions of heat-affected-zone (HAZ) and base- metal (BM) compact tension (CT) samples taken from the welded joint.

Table 4.5. Mechanical properties of 3Cr-2WV steel

\begin{tabular}{ll}
\hline \multicolumn{1}{c}{ Property } & \multicolumn{1}{c}{ Value } \\
\hline Yield strength & $919.8 \mathrm{MPa}$ \\
Ultimate tensile strength & $1025.9 \mathrm{MPa}$ \\
Total elongation & $16 \%$ \\
Reduction in area & $54 \%$ \\
\hline
\end{tabular}




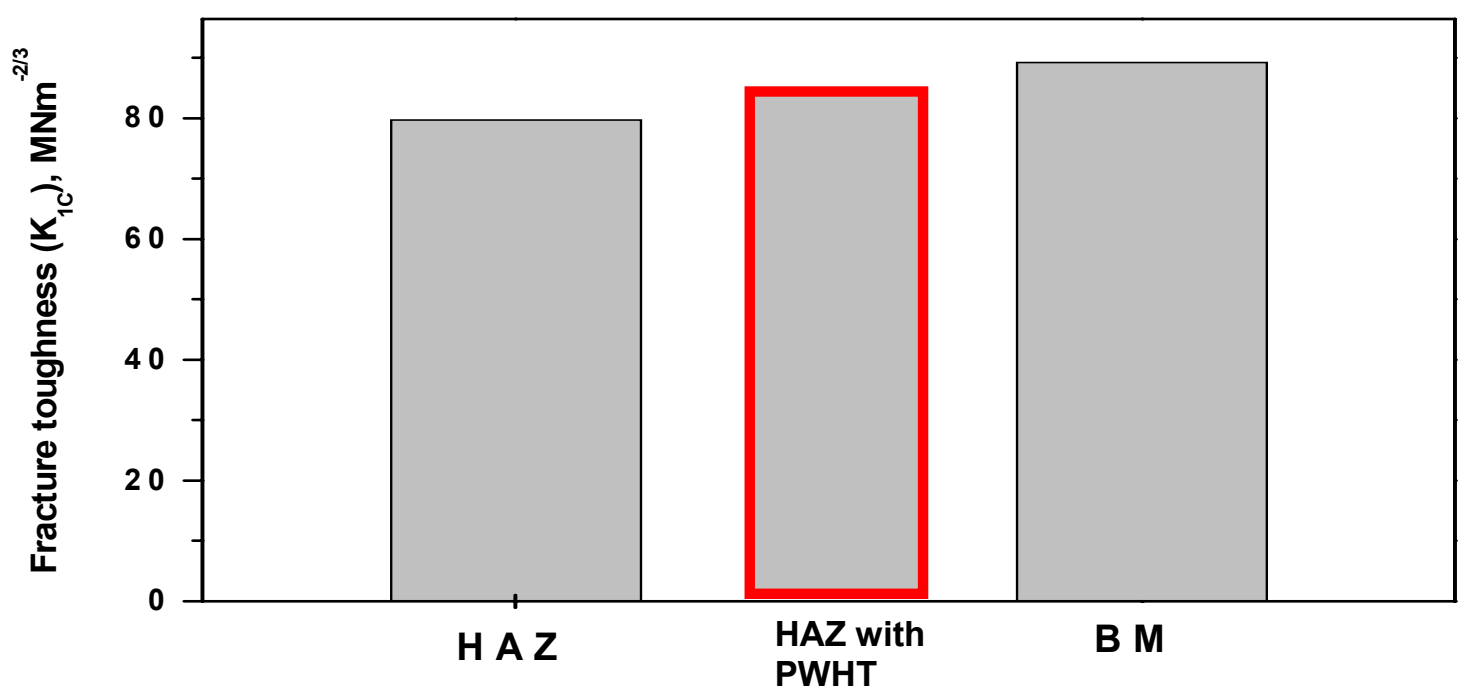

Fig. 4.18. Comparison of fracture toughness between of heat-affected zone (HAZ) and base metal (BM).
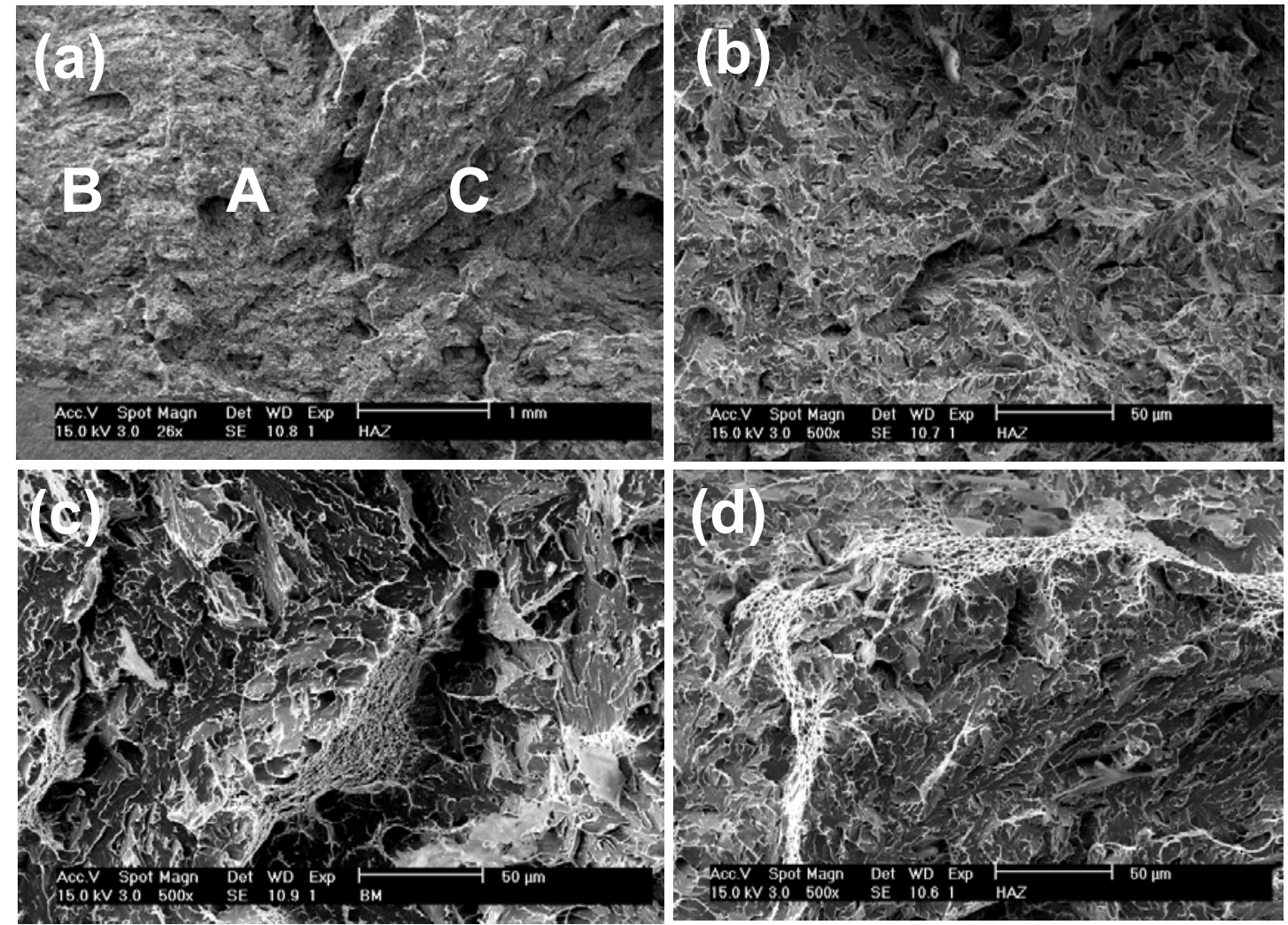

Fig. 4.19. Scanning electron microscopy fractographs of HAZ specimens: (a) low-magnification image showing fracture through heat-affected zone $(A)$, weld metal $(B)$, and base metal $(C)$ in a HAZ compact tension specimen; (b) typical fractograph of HAZ; (c) typical fractograph of BM; (d) typical fractograph of WM. 

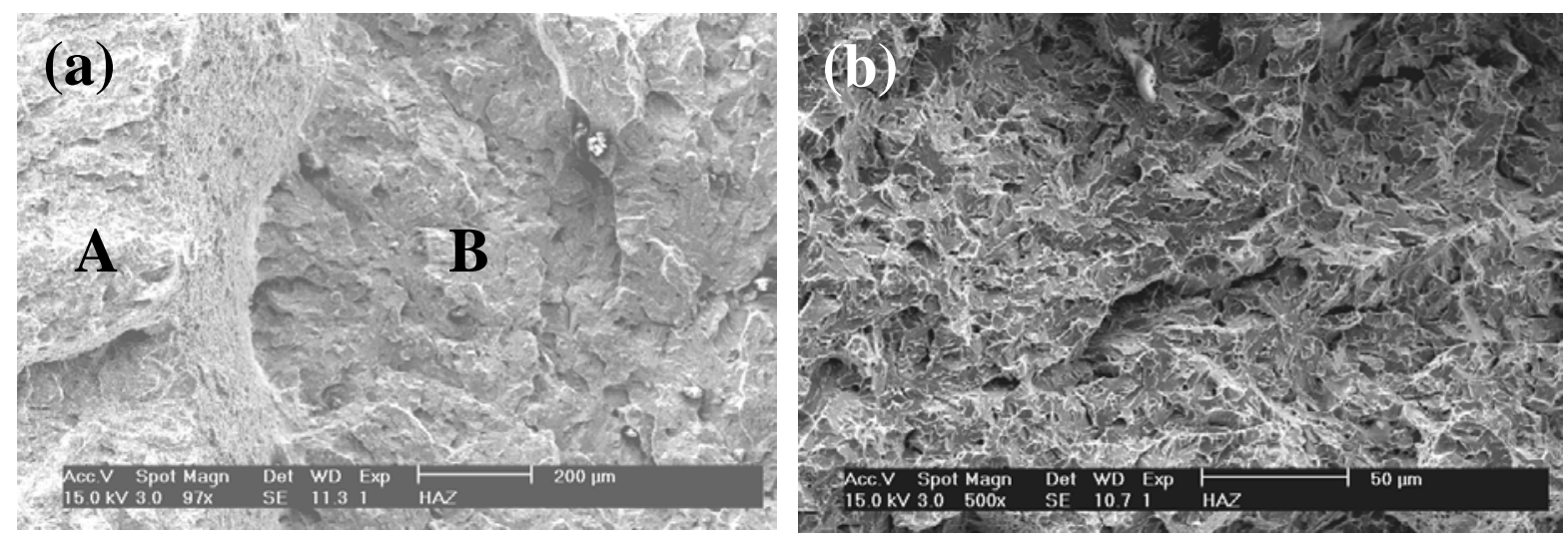

Fig. 4.20. Scanning electron microscopy fractographs of HAZ specimen with and without PWHT: (a) lowmagnification image showing fracture through base metal $(A)$ and heat-affected zone $(B)$ in a HAZ CT specimen with PWHT; (b) typical fractograph of HAZ without PWHT. 


\section{Accomplishments}

\subsection{Technical Accomplishments}

The following are the technical accomplishments of this project:

1. The microstructures of both the $3 \mathrm{Cr}-3 \mathrm{WV}$ and the $3 \mathrm{Cr}-3 \mathrm{WVTa}$ steels were found to be acicular bainite. An addition of tantalum to $3 \mathrm{Cr} 3 \mathrm{WV}$ steel substantially decreases the prior austenite grain size, but has less effect on bainite packet size.

2. Small TaC precipitates were found in the N 3Cr-3WVTa specimen, whereas no precipitates could be detected in 3Cr-3WV steel after normalizing.

3. After the $3 \mathrm{Cr} 3 \mathrm{WVTa}$ steel was tempered, additional fine TaC particles were precipitated and separated within the grains. The size of carbides at prior austenite grain boundaries was smaller in the 3Cr3WVTa steel than in the 3Cr-3WV steel.

4. Compared to 3Cr-3WV steel, the 3Cr-3WVTa steel had higher strength, which resulted from secondary-phase precipitation mechanisms, and relatively higher fracture toughness, especially under the NT condition.

5. Results from fracture toughness testing demonstrated that tungsten inert gas welding is a good solution for the joining of $3 \mathrm{Cr}-2 \mathrm{WV}$ steel. The fracture toughness of the welded joint is comparable to that of base metal even without PWHT.

\subsection{Publications and Patents}

\subsubsection{Publications}

The following publication resulted from this project:

Z. Chen, Z. Shan, N. Q. Wu, V. K. Sikka, M. Hua, and Scott X. Mao, "Fine Carbides

Strengthened 3Cr-3WVTa Bainite Steels," Metallurgical and Materials Transactions A 35A (2004): 1281.

\subsubsection{Patents}

None.

\subsection{Commercialization}

The commercial use of Fe-3Cr-W(Mo)V steels requires ASTM specifications and ASME Code approval. The related project led by Nooter (reported in Development of a New Class of Fe-3Cr-W(V) Ferritic Steels for Industrial Process Applications [ORNL/TM-2005/82]) has already obtained ASME specifications for the plate product of the Fe-3Cr-W(Mo)V composition. The final alloy is called alloy 315; the ASTM specification is A1041-04. The ASME Code package is currently being reviewed by the appropriate code committees. Approval is expected by September 2006. Data from this project are helping answer questions regarding fracture toughness and the need for PWHT of welds. 



\section{Summary and Conclusions}

\subsection{Summary}

This project dealt with developing an understanding of the toughening and strengthening mechanisms for a new class of Fe-3Cr-W(V) steels developed at Oak Ridge National Laboratory (ORNL) in collaboration with Nooter Corporation and other industrial partners. The new steel had (a) $50 \%$ higher tensile strength at temperatures up to $650^{\circ} \mathrm{C}$ than current steels, (b) the potential for not requiring any postweld heat treatment (PWHT), and (c) the potential of reducing equipment weight by $25 \%$. This project was closely related to the Nooter project entitled Development of a New Class of Fe-3Cr-W(V) Ferritic Steels for Industrial Process Applications (ORNL/TM-2005/82). The project was carried out jointly by the University of Pittsburgh and ORNL. The University of Pittsburgh carried out fracture toughness measurements and microstructural analysis on the base metal and welded plates prepared at ORNL.

The project focused on three aspects. The first dealt with a detailed microstructural analysis of base compositions of $3 \mathrm{Cr}-3 \mathrm{WV}$ and $3 \mathrm{Cr}-3 \mathrm{WV}(\mathrm{Ta})$ in both $\mathrm{N}$ and $\mathrm{NT}$ conditions. The second aspect dealt with the determination of tensile properties and fracture toughness values of $K_{I C}$ at room temperature for both $3 \mathrm{Cr}-3 \mathrm{Wv}$ and $3 \mathrm{Cr}-3 \mathrm{WV}(\mathrm{Ta})$ compositions. The third aspect of the project was to measure the fracture toughness values of the base metal and the heat-affected zone (HAZ) of a plate of $\mathrm{Fe}-3 \mathrm{Cr}-$ $\mathrm{W}(\mathrm{Mo}) \mathrm{V}$ steel plate welded by the gas tungsten arc (GTA) process. The HAZ toughness was measured in both the as-welded and the PWHT condition.

Both $3 \mathrm{Cr}-3 \mathrm{WV}$ and $3 \mathrm{Cr}-3 \mathrm{WV}(\mathrm{Ta})$ alloys showed the presence of an acicular bainitic structure. A tantalum addition of $0.1 \mathrm{wt} \%$ decreased the prior austenite grain size of $3 \mathrm{Cr}-3 \mathrm{WV}$ steel by nearly a factor of 2 . However, the bainite packet size was only slightly affected by the addition of tantalum. The tantalum-containing steel showed the presence of $\mathrm{TaC}$ in the $\mathrm{N}$ condition. No precipitates were observed in $3 \mathrm{Cr}-3 \mathrm{WV}$ steel in the $\mathrm{N}$ condition. A tempering treatment of $700^{\circ} \mathrm{C}$ resulted in carbide precipitation at the grain boundaries and in the matrix of $3 \mathrm{Cr}-3 \mathrm{WV}$ steel. For $3 \mathrm{Cr}-3 \mathrm{WV}(\mathrm{Ta})$; the tempering treatment also precipitated $\mathrm{TaC}$ at the grain boundaries and in the matrix. The carbide particle size at the grain boundaries and in the matrix was finer (by $\sim 1 / 2$ to $1 / 3$ ) for $3 \mathrm{Cr}-3 \mathrm{WV}(\mathrm{Ta}$ ) steel than for $3 \mathrm{Cr}-3 \mathrm{WV}$.

The $K_{I C}$ fracture toughness values of both $3 \mathrm{Cr}-3 \mathrm{WV}$ and $3 \mathrm{Cr}-3 \mathrm{WV}(\mathrm{Ta})$ were very similar under both $\mathrm{N}$ and NT conditions. After tempering, the $K_{I C}$ values of both steels improved by $\sim 10 \%$.

The GTA weld in the steel composition $3 \mathrm{Cr}-\mathrm{W}(\mathrm{Mo}) \mathrm{V}$, which was developed for commercial applications, was tested for its $K_{I C}$ values in the base metal and HAZ. The $K_{I C}$ values in HAZ were also determined after PWHT. Data showed that the $K_{I C}$ values of HAZ in the as-welded and PWHT conditions were similar to the values for the base metal. These observations suggest that the GTA welds can be used in the as-welded conditions.

\subsection{Conclusions}

The following major conclusions may be drawn from this project:

1. The collaboration between a university (the University of Pittsburgh) and a DOE national laboratory (ORNL) was key to the success of this project and to the success of the related 
industry-led project. The university research provided an understanding of the relationships between microstructure, processing, and material properties. ORNL's capabilities in alloy design and its laboratory- and pilot-scale development of the new materials were also important to the success of the project.

2. The role of universities in educating students for the $R \& D$ and industrial sectors also was important in this project. Two post-doctoral students participated in the project.

3. The project found that, compared to 3Cr-3WV steel, the 3Cr-3WVTa steel had higher strength, which resulted from secondary-phase precipitation mechanisms, and relatively higher fracture toughness, especially under the NT condition.

4. Results from fracture toughness testing demonstrated that tungsten inert gas welding is a good solution for the joining of $3 \mathrm{Cr}-2 \mathrm{WV}$ steel. The fracture toughness of the welded joint is comparable to that of base metal even without PWHT.

\subsection{Commercialization Aspects: Plans, Status, Barriers}

The outcome of this project is not directly involved in commercialization. However, the data from this project help in accelerating the ASME Code approval, which is a prerequisite for the commercial applications. The barrier is the need for additional fracture toughness data for welds prepared by submerged arc and shielded metal arc processes. 


\section{Recommendations}

Fracture toughness $\left(K_{I C}\right)$ measurements should be determined for the base metal, HAZ, and weld metal for submerged arc (SA) welded plates from the final steel compositions consisting of $3 \mathrm{Cr}$ $2 \mathrm{~W}(\mathrm{Mo}) \mathrm{V}$. This is needed because SA will be the process most commonly used for the production of chemical reaction vessels from these steels. 



\section{References}

1. Y. Sawaragi et al., pp. 287-294 in Heat-Resistant Materials II, ed. K. Natesan, P. Ganesan, and G. Lai (Materials Park, OH: ASM-International, 1995).

2. L. J. Habraken and M. Economopoulos, p. 69 in Transformation and Hardenability in Steels (Ann Arbor, MI: Climax-Molybdenum Co., 1967).

3. R. L. Klueh and A. M. Nasreldin, Metall. Trans. 18A (1987): 1279.

4. R. L. Klueh, D. J. Alexander, and E. A. Kenik, J. Nucl. Mater., 227 (1995); 11.

5. R. L. Klueh, D. J. Alexander, and P. J. Maziasz, Metall. Trans. 28A (1997): 335.

6. R. L. Klueh and P. J. Maziasz, "Cr-W-V Bainitic/Ferritic Steel with Improved Strength and Toughness and Methods of Making," U.S. Patent 5,292,384 (March 8, 1994).

7. R. L. Klueh, pp. 617-652 in Properties and Selection: Irons, Steels and High-Performance Alloys, vol. 1 of The Metals Handbook, 10th ed. (Materials Park, OH: ASM-International, 1990).

8. R. L. Klueh and P. J. Maziasz, Metall. Trans. 20A (1989): 373.

9. R. L. Klueh and A. M. Nasreldin, Metall. Trans. 18A (1987): 1279-90.

10. H. Schick, Thermodynamics of Certain Refractory Compounds, Vol. 1 (New York: Academic Press, 1996).

11. J. P. Naylor and P. R. Krahe, Metall. Trans. 5A (1974): 1699.

12. R. Jayaram and R. L. Klueh, Metall. Trans. 29A (1998): 1551.

13. J. G. Nawrocki et al., Metall. Trans. 32A (2001): 2585.

14. R. L. Klueh, D. J. Alexander, and P. J. Maziasz, Metall. Trans. 28A (1997): 335.

15. G. T. Hahn, Metall. Trans. 15A (1984): 947.

16. R. L. Klueh and D. R. Harries, High-Chromium Ferritic and martensitic Steels for Nuclear Applications (West Conshohocken, PA: American Society for Testing and Materials, 2001).

17. P. Bowen, S. G. Druce, and J. F. Knott, Acta Metall. 34 (1986): 1121.

18. D. A. Curry and J. F. Knott, Met. Sci. 12 (1978): 511.

19. N. J. Petch, Acta Metall. 34 (1986): 1387.

20. E. A. Brandes, Smithell's Metals Reference Book, 6th ed. (London: Butterworth, 1983). 